\title{
Biochemical Mediators Involved in Cartilage Degradation and the Induction of Pain in Osteoarthritis
}

\author{
Michael B. Ellman ${ }^{1,2}$, Dongyao Yan ${ }^{1}$, Di Chen ${ }^{1}$ and Hee-Jeong $\operatorname{Im}^{1,2,3}$ \\ ${ }^{1}$ Department of Biochemistry, \\ 2 Department of Orthopedic Surgery, \\ ${ }^{3}$ Department of Internal Medicine, \\ Section of Rheumatology, Rush University Medical Center, Chicago, IL,
}

USA

\section{Introduction}

Osteoarthritis, a debilitating degenerative joint disease predominantly found in elderly individuals, has become the principal source of physical disability resulting in increased health care costs and impaired quality of life in the United States. The pathogenesis of osteoarthritis (OA) involves the progressive deterioration of cartilage tissue, but many of the underlying biochemical and pathophysiological mechanisms involved in cartilage degradation and the induction of pain in this process remain largely unknown. Recent literature has focused on understanding many of these processes, with the intention of developing novel therapies aimed at slowing and/or reversing cartilage degradation and inducing symptomatic relief. This chapter provides an overview of several biochemical mediators involved in $\mathrm{OA}$, with an emphasis on reviewing pertinent factors mediating cartilage breakdown and the induction of pain in degenerative conditions.

\section{Anatomy}

Articular cartilage lines the surfaces of joints and serves several important functions, including the provision of a smooth, low-friction surface, joint lubrication, and stress distribution with load bearing $(1,2)$. The components of articular cartilage include an elaborate mixture of water (65-80\% of wet weight), collagen $(10-20 \%$ of wet weight), proteoglycans (PGs; $10-15 \%$ of wet weight), and chondrocytes (5\% of wet weight) (1). The extracellular matrix (ECM) includes collagen and PGs, principally aggrecan, with other proteins and glycoproteins in lesser amounts. This matrix allows normal cartilage to form the resilient, low-friction surface capable of absorbing shock with high impact mechanical loading (3).

Within the ECM, collagen fibers provide form, shape, and tensile strength to cartilage. The principal collagen fibers present in articular cartilage are type II fibers, with smaller quantities of types V, VI, IX, X, and XI (1). Collagen interacts to form fibrils that interact with and trap large aggregates of PGs, principally aggrecan. PGs bind water and help 
distribute stresses throughout the porous-permeable ECM under compressive loads. Aggrecan, the most abundant PG found in articular cartilage, is composed of a protein backbone bound by negatively-charged chondroitin sulfate and keratin sulfate groups. It binds with hyaluronic acid (HA) to form complexes within the ECM. Due to negativelycharged sulfated groups, these complexes electrostatically interact with cations, ultimately forming ion-dipole interactions with water, allowing cartilage to function as a hydrated tissue that resists compression.

The cellular makeup of cartilage consists of articular chondrocytes. Chondrocytes maintain and produce the components of the ECM that regulate cartilage homeostasis. They are mesenchymal in origin, few in number within the matrix, have a low rate of cell turnover, and receive nutrients and oxygen from the surrounding synovial fluid by means of diffusion (1). Further, they respond to a variety of factors, including matrix proteins, mechanical load, and soluble mediators such as growth factors and cytokines.

\section{Metabolic disruption of cartilage homeostasis in osteoarthritis}

Under normal conditions, chondrocytes maintain a dynamic equilibrium between synthesis and degradation of ECM components. In osteoarthritic states, however, there is a disruption of matrix equilibrium leading to progressive loss of cartilage tissue, clonal expansion of cells in the depleted regions, induction of oxidative states in a stressful cellular environment, and eventually, apoptosis of chondrocytes $(2,4)$. With progression, there is usually an increase in both degradation and synthesis within the joint, with an overall shift toward catabolism over anabolism. Chondrocyte metabolism is unbalanced due to excessive production of inflammatory cytokines and matrix-degrading enzymes, in conjunction with a downregulation of anabolic factors, eventually leading to destruction of the ECM and subsequent cartilage degradation. Oxidative stress elicited by reactive oxygen species (ROS) further disturbs cartilage homeostasis and promotes catabolism via induction of cell death, breakdown of matrix components, upregulation of latent matrix-degrading enzyme production, inhibition of ECM synthesis, and oxidation of intracellular and extracellular molecules (2).

One approach to slow or reverse catabolism involves attempts to downregulate the expression of catabolic factors and/or matrix-degrading enzymes, including matrix metalloproteases (MMPs) and a disintegrin-like and metalloprotease with thrombospondin motifs (ADAMTS family, aka aggrecanases)(5). In particular, MMP-13 is the most potent collagen type II-degrading enzyme in human articular cartilage (6). The regulation of matrix-degrading enzyme expression is stimulated by pro-inflammatory cytokines, growth factors, and metabolites, including lipopolysaccharide (LPS) (7), interleukin-1 (IL-1) (8), tumor necrosis factor-alpha (TNF-a) (8), fibroblast growth factor-2 (FGF-2, otherwise known as basic FGF) (9), and ROS (10). Equally important are attempts to upregulate anabolic factors in matrix homeostasis, including ECM components (e.g., aggrecan, collagen type II), growth factors (e.g. transforming growth factor (TGF)- $\beta$, bone morphogenetic proteins (BMPs), and insulin-like growth factor-1 (IGF-1)), and/or anti-destructive enzymes [e.g., tissue inhibitor of metalloproteases (TIMPs)] to prevent cartilage degradation.

\section{Catabolic mediators in OA}

Healthy articular chondrocytes and synoviocytes constitutively synthesize and secret a wide array of mediators to maintain their delicate homeostasis. When inappropriately regulated, 
a subset of mediators will drive detrimental catabolic processes in both cell populations, resulting in cartilage degeneration and chronic synovial inflammation. This section will summarize our current understanding of these key catabolic factors in OA pathogenesis.

\subsection{Inflammatory mediators}

Typical inflammatory mediators in OA include pro-inflammatory members from the interleukin family (IL-1, IL-6, and IL-17), TNF-a, and prostaglandin E2 (PGE2). The roles of these mediators have been extensively studied in arthritic tissues secondary to their high concentrations in degenerative states. Each of these mediators not only stimulates the production of cartilage-degrading proteases, but also upregulates other destructive factors via paracrine or autocrine mechanisms, thus perpetuating disease progression.

\subsubsection{IL-1 $\beta$}

IL-1 $\beta$ is thought to play a prominent role in OA development. It demonstrates potent bioactivities in inhibiting ECM synthesis and promoting cartilage breakdown. Independent studies have shown that IL-1 $\beta$ represses the expression of essential ECM components, aggrecan and collagen type II, in chondrocytes (11-13). IL-1 $\beta$ also strikingly induces a spectrum of proteolytic enzymes, including collagenases (MMP-1 and MMP-13) and ADAMTS-4, in both chondrocytes and synovial fibroblasts. Aside from these direct effects, IL-1 $\beta$ induces a panel of cytokines, including IL-6, IL-8, and leukemia inducing factor (LIF), which produce additive or synergistic effects in the catabolic cascade (14). Further, IL-1 $\beta$ has been implicated in OA pathogenesis in numerous observational studies. Although less pronounced than what has been observed in rheumatoid arthritis patients, OA synovial fluids contains significantly higher levels of IL-1 $\beta$ compared to normal synovial fluid (15). Immunohistochemical analyses also reveal increased expression of IL-1 $\beta$ in OA cartilage and synovium $(16,17)$. Moreover, osteoarthritic chondrocytes exhibit heightened sensitivity to IL-1 $\beta$ stimulation, in part due to augmented IL-1 receptor type I expression (18). This pathological change renders OA chondrocytes even more susceptible to deleterious IL- $1 \beta$ attack. The significance of IL-1 $\beta$ in OA was further corroborated by in vivo studies and pharmaceutical efforts using IL-1 receptor antagonist (IL-1ra) as a potential therapeutic factor to prevent cartilage degeneration. As an inhibitory molecule of IL-1 $\beta$, IL-1ra not only showed efficacy in OA animal models, but also improved clinical outcomes (19).

\subsubsection{IL-6}

Another constitutively expressed cytokine in human articular chondrocytes is IL-6 (20), yet only a fraction of OA patients contains increased IL-6 levels in arthritic cartilage and synovial fluid, suggesting that IL-6 may not be the ultimate driving force in this disease (21, 22). Nevertheless, in vitro studies demonstrate catabolic effects of IL-6 as this cytokine inhibits PG synthesis in chondrocytes, and this effect is potentiated by addition of soluble IL-6 receptor (sIL-6R) $(23,24)$. Combination treatment with IL-6 and sIL-6R has been shown to enhance aggrecanase-mediated PG depletion in cartilage (25). IL-6 also suppresses collagen type II expression (26), and to a lesser extent than IL-1 $\beta$, dysregulates enzymatic antioxidant defense mechanisms in chondrocytes via modulation of key enzymes (27). Therefore, it is surprising that male IL-6/- mice displayed more severe OA phenotypes compared with wild-type mice (28). In this report, de Hooge et al suggest that IL-6 exerted joint protection in aging murine OA joints. However, their findings differ qualitatively from 
those provided by Ryu et al, who reported that IL-6 promotes joint destruction in an instability-induced OA model (29). Further in vivo experiments are warranted to clarify such contradictions. Interestingly, a recent study suggested a mechanistic link between obesity and OA, based on the observation that the infrapatellar fat pad actively synthesizes IL- 6 and sIL-6R in knee OA patients (30).

\subsubsection{IL-17}

The pro-inflammatory role of IL-17 is well-established in rheumatoid arthritis, but less so in OA. IL-17 is reported to exert stimulatory effects on MMP-3, MMP-13 and ADAMTS-4 expression in chondrocytes $(31,32)$. It directly inhibits PG synthesis, augments nitric oxide production, and triggers angiogenic factor release (33-35). Further, the IL-17 response can be amplified dramatically when other destructive cytokines, such as IL-1 $\beta$ and TNF- $\alpha$, are present. In chondrocytes, IL-17-mediated type II collagen breakdown and MMP expression is synergistically enhanced by IL-1, IL-6, or TNF-a co-treatment (36). Likewise, synergy in nitric oxide production was observed when chondrocytes were treated with IL-17 and TNFa (37). IL-17 also synergizes with IL-1 $\beta$ or TNF-a in PGE2 production in OA menisci ex vivo (38). Cytokine induction serves as a secondary mechanism in IL-17-mediated effects. In chondrocytes and synovial fibroblasts, IL-17 induces certain pro-inflammatory cytokines and chemokines, such as IL-1 $\beta$, IL-6, and IL-8 $(39,40)$. In macrophages, IL-17 effectively upregulates IL-1 and TNF-a expression, which may contribute to chronic synovial inflammation observed in some OA patients (41). By way of adenovirus-mediated IL-17 overexpression, Koenders et al. showed that IL-17 is capable of causing joint inflammation and bone erosion by itself, and also synergizes with TNF-a (42). Conversely, IL-17 deficiency markedly mitigates the arthritic phenotype in a collagen-induced arthritis model, but whether IL-17 ablation also provides similar protection in OA models awaits investigation (43).

\subsubsection{TNF- $\alpha$}

The relevance of TNF- $a$ to OA pathogenesis is supported by the observation that TNF- $\mathrm{A}$ receptor expression is significantly upregulated in OA cartilage $(44,45)$. TNF- $\mathrm{O}$ concentration in synovial fluid also increases in patients with anterior cruciate ligament injury, suggesting this cytokine may play a role in OA development (46). Similar to IL-1 $\beta$, TNF-a also promotes PG depletion (47-49). The induction of proteolytic enzymes MMP-3, MMP-9, and MMP-13 by TNF-a in chondrocytes may account for such an action $(50,51)$. TNF-a potently induces IL-6 and PGE2, which possibly results in secondary inflammatory events in the joint $(47,48,52,53)$. Another important process mediated by TNF-a is cell death. It appears that excessive exposure to TNF-a can elicit chondrocyte apoptosis, which will lead to local secondary necrosis and eventually a catabolic cascade due to absence of phagocytes in cartilage $(54,55)$. Consistent with these findings, TNF-a transgenic mice exhibit spontaneous cartilage damage and conspicuous occurrence of arthritis (54).

\subsubsection{PGE2}

PGE2 is yet another significant player in chondrocyte metabolism. Upregulated in OA, PGE2 inhibits PG and type II collagen synthesis with the highest cellular sensitivity among all prostanoids produced by chondrocytes $(56,57)$. Mechanistically, PGE2 appears to signal through the EP2 receptor to exert such inhibitory effects (58). Furthermore, EP4 receptor 
activation increases MMP-13 and ADAMTS-5 expression, thus promoting ECM degradation (59). Interestingly, some evidence suggests that specific EP2 activation enhances cartilage regeneration in rabbit models, indicating species differences in PGE2 responses (60). PGE2 also mediates or sensitizes chondrocytes to apoptosis $(61,62)$. Both IL-1 and TNF- $a$ induce PGE2 production, with the former being more potent (63-65), and the involvement of PGE2 in IL-1 $\beta$-induced MMP-3 and MMP-13 expression is demonstrated in PGE synthase-1 knockout chondrocytes. In these modified cells, the catabolic effects of IL-1 $\beta$ are dramatically reduced (66). However, another group claims that PGE2 acts as a secretagogue of IGF-1, which in turn mediates anabolism in chondrocytes (67). Whether this induction brings any benefit to OA cartilage is questionable, because IGF-1 non-responsiveness has been reported in OA chondrocytes (68).

\subsection{Oxidative stress mediators, growth factors and glycoproteins \\ 4.2.1 Nitric oxide}

Nitric oxide (NO), a member of ROS, mediates the destructive actions of IL-1 $\beta$ and TNF- $\alpha$ in cartilage, including suppression of PG and collagen synthesis, as well as stimulation of MMPs (69-73). Spontaneous overproduction of NO produces similar effects in chondrocytes $(73,74)$, and prolonged exposure to NO together with other ROS can lead to apoptosis of articular cell types $(62,75,76)$. NO is also partially responsible for the insensitivity of OA chondrocytes to IGF-1 (77). As a mediator downstream of IL-1, NO also inhibits BMP-2mediated PG synthesis (78).

Inducible nitric oxide synthase (iNOS) is the major enzyme responsible for NO generation in articular cartilage. OA chondrocytes in the superficial zone express higher levels of iNOS $(79,80)$. Several destructive cytokines, including IL-1 and TNF- $a$, induce iNOS expression in articular cell types $(81,82)$. Forced expression of iNOS inhibits matrix synthesis in chondrocytes (74). Futher, in OA cartilage, iNOS inhibition gives rise to IL-10 induction and MMP-10 repression in the presence of IL-1 $\beta$ (83). More recently, iNOS was found to function as a crucial mediator downstream of the advanced glycation end products pathway and the leptin pathway in chondrocytes $(84,85)$. Pelletier et al provided compelling evidence regarding the importance of iNOS in OA progression. In their canine OA model, selective inhibition of iNOS resulted in marked attenuation of joint destruction (86). Intra-articular delivery of an iNOS inhibitor counteracts the acute effects mediated by IL-1 $\beta$, reaffirming the catabolic role of iNOS in OA progression (87).

\subsubsection{FGF-2}

A series of studies have demonstrated that FGF-2 (otherwise known as basic FGF) acts as a catabolic growth factor in addition to its well-established mitogenic role in articular cartilage. Despite its positive effect on proliferation, FGF-2 inhibits IGF-1/BMP-7-enhanced PG deposition in human articular chondrocytes, and negatively affects the physical properties of normal cartilage $(88,89)$. FGF-2 alters the ratio of type II to type I collagen in articular chondrocytes, thus possibly leading to the formation of fibrocartilage, a poor substitute for hyaline cartilage $(90,91)$. In porcine chondrocytes, FGF-2 antagonizes IGF$1 /$ TGF- $\beta$-mediated decorin and type II collagen production (92). Moreover, FGF-2 promotes cartilage degeneration ex vivo (93). A mechanistic explanation of FGF-2-mediated effects lies in its ability to upregulate MMP-13 and ADAMTS-5 $(94,95)$. FGF-2 orchestrates the MAPK, NFKB, and substance P signaling pathway to induce MMP-13 $(5,93,94)$. It has also been 
shown that activation of FGF receptor 1 (FGFR1) is required for FGF-2-mediated MMP-13 and ADAMTS-5 induction (95).

Results acquired from comparative analyses suggest the biological relevance of FGF-2 to OA. FGF-2 levels in OA synovial fluids are significantly elevated compared to those in normal specimens (94). FGFR3 expression is markedly diminished in OA chondrocytes, which results in altered FGFR1 to FGFR3 ratios and may account for the inhibition of anabolism in the disease state (95). It should be noted that other studies indicate a chondroprotective role of FGF-2 in cartilage biology $(96,97)$. The discrepancies may arise from differences in cell origin (i.e. species, age, severity of $\mathrm{OA}$, etc), and render future clarifications necessary.

\subsubsection{Fibronectin}

Fibronectin (Fn) is an adhesive glycoprotein found in cartilage and synovial membrane tissue (98). Evidence shows that Fn level is increased in OA cartilage as well as OA synovial fluid $(99,100)$. Heightened proteolytic activities in OA joints lead to the generation of Fn fragments (Fn-fs) of different sizes. Specifically, ADAMTS-8 was characterized as a fibronectinase in OA chondrocytes (101). Indeed, Fn-fs are found with increased abundance in OA synovial fluids and cartilage $(99,102)$. A 40-kDa collagen-binding Fn-f induces sustained PG degradation in both normal and OA cartilage (103). Furthermore, Fn-f stimulates type II collagen cleavage in an MMP-13-dependent manner (104). Preceding collagen disintegration, Fn-f disrupts the ECM by promoting the release of cartilage oligomeric matrix protein (COMP) and chondroadherin (105). Fn-f also augments cytokine, ROS, MMP and aggrecanase production in cartilage ex vivo and in vitro (10, 106-109). Stimulation of IL-1 leads to enhanced production of Fn-f, which exerts prolonged destructive effects (99).

\subsubsection{Osteopontin}

Osteopontin, a phosphorylated glycoprotein with cell and matrix binding affinities, has been characterized as a facilitator of osteoclast adhesion and an initiator of osteoid mineralization (110). Osteopontin deposition in cartilage exhibits a spatial pattern, based on the fact that it is mainly detected in chondrocytes residing in the upper deep zone (111). Comparative analyses reveal that, in contrast with healthy chondrocytes, OA chondrocytes express notable levels of osteopontin (111). Moreover, an apparent correlation exists between osteopontin level and the severity of OA lesions (111-113).

Nevertheless, the role of osteopontin in cartilage remains controversial. Osteopontin promotes calcium pyrophosphate dehydrate (CPPD) crystal formation in articular cartilage, suggesting that elevated osteopontin production in OA may be detrimental (114). Yet this stimulatory effect seems to depend on osteopontin concentration, because other studies demonstrate the opposite using higher concentrations of this protein (115). Another independent study also showed that osteopontin inhibits IL- $1 \beta$-induced NO and PGE2 production in OA cartilage, suggesting an anti-catabolic role in cartilage homeostasis (116). Osteopontin deficiency exacerbates aging-induced and instabilityinduced OA in mice (117). Based on these apparently contradictory activities, it raises the possibility that osteopontin elicits different biological effects depending on the stages of OA. 


\subsubsection{Osteonectin}

Osteonectin is a non-collagenous glycoprotein linking collagen fibrils to mineral in bone. It is also present in mineralizing chondroid bone (118). Articular chondrocytes synthesize osteonectin, and this process is regulated by endogenous stimuli. IL-1, TNF-a, and FGF-2, but not IL-6, greatly inhibit osteonectin expression $(119,120)$. IL-1 also impairs the glycosylation of osteonectin (120). On the other hand, TGF- $\beta$, PDGF, and IGF-1 upregulate osteonectin synthesis, even in the presence of IL-1 $(119,120)$. Osteonectin is localized to the superficial and middle zones of OA cartilage, while normal cartilage does not display such a pattern $(120,121)$. Osteonectin synthesis is also enhanced in OA synovial fibroblasts (120). Osteonectin induces collagenase expression in this cell type, which may contribute to cartilage damage (122).

\subsection{Protective mediators in OA}

In contrast to the aforementioned catabolic mediators in OA, several growth factors take on important anabolic roles in the joint, thus serving as potential targets for future therapeutic growth factor therapy in practice. While the literature has only begun to explore the in vitro, in vivo, and clinical effects of many of these factors, there is potential for these mediators to be major players in the treatment of degenerative joint diseases in the future. Multiple cytokines exert protection in articular joints, including IL-1 receptor antagonist (IL-1ra), IL-4, IL-10, IL-11, and IL-13. Perhaps the most well-studied anabolic factors to date include TGF$\beta$, BMP-2, BMP-7, and IGF-1 (Table 1). We will also discuss two factors elucidated in our laboratory to have potent anabolic and anti-catabolic effects in human articular cartilage: resveratrol (RSV) and bovine lactoferricin (LfcinB).

\subsubsection{Interleukins}

The antagonistic effect of IL-1ra on IL-1 has been well established. By directly competing against IL-1 for its cognate receptor, IL-1ra effectively inhibits IL-1-mediated responses in chondrocytes, including PG depletion, MMP induction, and cytokine induction (123-125). IL-1ra expression is repressed by NO, which may blunt its action in OA cartilage (126). Not surprisingly, forced expression of IL-1ra confers resistance to IL-1 challenge in chondrocytes $(127,128)$. Both gene delivery and IL-1ra intra-articular injection have been shown to impede OA progression, indicating anti-IL-1 therapy is a viable option in OA disease modification $(19,129)$.

Protective roles of anti-inflammatory cytokines have also been linked to OA. An array of cytokines, including IL-4, IL-10, IL-11, and IL-13, has been shown to block the actions of catabolic cytokines via different mechanisms. IL-4 suppresses MMP-13, cathepsin B, and iNOS when cyclic tensile stress is applied on chondrocytes $(130,131)$. IL-4 has potent inhibitory effects on cartilage degradation in the presence of IL-1 and TNF-a (132). In synoviocytes, IL-4 downregulates apoptosis (133). IL-4 gene therapy appears to dampen inflammation in chondrocytes (134). Moreover, intra-articular injection of IL-4 results in notable amelioration of cartilage degenerative status (131).

IL-10 is upregulated in OA chondrocytes, and this phenomenon may represent a reparative effort (135). IL-10 suppresses IL-1 and TNF-a production (136). Compared to IL-1ra, IL-10 gene delivery into synoviocytes elicits moderate yet still significant protection on cartilage (137). 


\begin{tabular}{|l|l|}
\hline IL-1 $\beta$ & $\begin{array}{l}-: \downarrow \text { PG synthesis; } \downarrow \text { type II collagen synthesis; } \uparrow \text { MMPs; } \uparrow \text { ADAMTS-4; } \uparrow \\
\text { ROS; } \uparrow \text { IL-6; } \uparrow \text { IL-8; } \uparrow \text { LIF; } \uparrow \text { synovial inflammation }\end{array}$ \\
\hline IL-6 & $\begin{array}{l}-: \downarrow \text { PG synthesis; } \downarrow \text { type II collagen synthesis; } \uparrow \text { PG depletion; } \\
\text { dysregulation of antioxidant defense }\end{array}$ \\
\hline IL-17 & $\begin{array}{l}-: \downarrow \text { PG synthesis; } \uparrow \text { type II collagen breakdown; } \uparrow \text { MMPs; } \uparrow \text { ADAMTS-4; } \uparrow \\
\text { NO; } \uparrow \text { IL-1 } \beta ; \uparrow \text { IL-6; } \uparrow \text { IL-8; } \uparrow \text { PGE2 (in menisci); } \uparrow \text { TNF-a (in macrophage) }\end{array}$ \\
\hline TNF-a & $-: \uparrow$ PG depletion; $\uparrow$ MMPs; $\uparrow$ IL-6; $\uparrow$ PGE2; $\uparrow$ chondrocyte apoptosis \\
\hline PGE2 & $\begin{array}{l}-: \downarrow \text { PG synthesis; } \downarrow \text { type II collagen synthesis; } \uparrow \text { MMPs; } \uparrow \text { ADAMTS-5; } \uparrow \\
\text { chondrocyte apoptosis }\end{array}$ \\
\hline NO & $\begin{array}{l}-: \downarrow \text { PG synthesis; } \downarrow \text { type II collagen synthesis; } \uparrow \text { MMPs; } \downarrow \text { IGF-1 sensitivity; } \\
\uparrow \text { apoptosis }\end{array}$ \\
\hline FGF-2 & $\begin{array}{l}-: \downarrow \text { PG deposition; } \downarrow \text { ratio of type II to type I collagen; } \uparrow \text { MMP-13; } \uparrow \\
\text { ADAMTS-5 }\end{array}$ \\
\hline Fn-f & $\begin{array}{l}-: \uparrow \text { PG degradation; } \uparrow \text { type II collagen cleavage; } \uparrow \text { COMP and } \\
\text { chondroadherin release; } \uparrow \text { MMPs; } \uparrow \text { aggrecanases; } \uparrow \text { destructive cytokines }\end{array}$ \\
\hline Osteopontin & $\begin{array}{l}-: \uparrow \text { CPPD formation } \\
+: \downarrow \text { NO; } \downarrow \text { PGE2 (concentration-dependent) }\end{array}$ \\
\hline Osteonectin & $-: \uparrow$ collagenases (in synovial fibroblasts) \\
\hline
\end{tabular}

$(-)=$ Catabolic effects; $(+)=$ Anabolic or anti-catabolic effects

Table 1. Effects of Catabolic Mediators in Articular Cartilage

\begin{tabular}{|c|c|}
\hline IL-1ra & $+: \downarrow$ IL-1-mediated responses \\
\hline IL-4 & $\begin{array}{l}+: \downarrow \text { MMP-13; } \downarrow \text { cathepsin B; } \downarrow \text { iNOS; } \downarrow \text { synovial fibroblast apoptosis; } \downarrow \text { IL- } \\
1 / \text { TNF-a-mediated cartilage degradation }\end{array}$ \\
\hline IL-10 & $+: \downarrow$ IL-1; $\downarrow$ TNF-a; $\uparrow$ cartilage protection \\
\hline IL-11 & $\begin{array}{l}+: \uparrow \text { TIMP-1; } \downarrow \text { pro-inflammatory cytokines; } \downarrow \text { NO; } \downarrow \text { TNF-a responses } \\
\text { (synovial fibroblast) }\end{array}$ \\
\hline IL-13 & $\begin{array}{l}+: \downarrow \text { MMPs; } \downarrow \text { IL-1 } \beta ; \downarrow \text { TNF-a; } \uparrow \text { IL-1ra; } \downarrow \text { PGE2 and COX-2 (synovial } \\
\text { fibroblasts); } \downarrow \text { synoviocyte apoptosis }\end{array}$ \\
\hline TGF- $\beta$ & $\begin{array}{l}+: \uparrow \text { chondrocyte activity, } \uparrow \text { PG synthesis, } \uparrow \text { ECM synthesis; } \downarrow \text { IL-1, } \downarrow \text { ROS } \\
\text { - : Osteophyte formation and synovial inflammation with prolonged exposure }\end{array}$ \\
\hline BMP-2 & $\begin{array}{l}+: \uparrow \text { ECM synthesis, } \uparrow \text { collagen II expression } \\
-: \quad+/ \text { - aggrecan degradation? }\end{array}$ \\
\hline BMP-7 & $\begin{array}{l}+: \uparrow \text { chondrocyte activity, } \uparrow \text { PG synthesis, } \uparrow \text { ECM synthesis; } \downarrow \text { cell proliferation; } \\
\text { age-independent, } \uparrow \text { activity of other anabolic factors (IGF-1, BMPs), } \downarrow \text { MMPs, } \\
\downarrow I \text { IL- } 1 \text { and IL-6; } \uparrow \text { cartilage repair in vivo (sheep, rabbits) } \\
\text { - : Unknown }\end{array}$ \\
\hline IGF-1 & $\begin{array}{l}+: \uparrow \text { ECM synthesis, } \uparrow \text { PG synthesis; } \downarrow \text { apoptosis; + synergism with BMP-7 } \\
-: \downarrow \text { effect with } \uparrow \text { age and on OA cartilage }\end{array}$ \\
\hline RSV & $\begin{array}{l}\text { +: } \uparrow \text { ECM synthesis, } \uparrow \text { PG (aggrecan) synthesis; } \uparrow \text { collagen II expression; } \downarrow \text { IL-1 } \\
\& \text { FGF-2 effects, + synergism with BMP-7 } \\
\text { - : preliminary data; no in vivo studies }\end{array}$ \\
\hline LfcinB & $\begin{array}{l}+: \uparrow \text { ECM synthesis, } \uparrow \text { PG (aggrecan) synthesis; } \uparrow \text { collagen II expression; } \downarrow \text { IL-1 } \\
\text { \& FGF-2 effects , + synergism with BMP-7 } \\
\text { - : preliminary data; no in vivo studies }\end{array}$ \\
\hline
\end{tabular}

Table 2. Effects of Protective Mediators in Articular Cartilage 
IL-11, an IL-6 family member, is believed to exert anti-catabolic and anti-inflammatory effects in articular joints, but remains poorly defined. IL-11 produced by articular chondrocytes stimulates the production of tissue inhibitor of metalloproteinase (TIMP) (138). IL-11 also downregulates pro-inflammatory cytokines and NO production (139). In OA synovial fibroblasts, IL-11 alone had no impact on PGE2 release, but shows antiinflammatory properties in conjunction with TNF- $\alpha$ (140). In RA synovium, IL-11 directly inhibits MMP-1 and MMP-3 production, upregulates TIMP-1, and inhibits TNF- $\alpha$ production in the presence of soluble IL-11 receptor (141). Importantly, systemic treatment with IL-11 leads to a significant reduction in clinical and histological severity of established collagen-induced arthritis (CIA), suggesting an active role of IL-11 in joint homeostasis (142). IL-11 level is greatly increased in OA synovial fluid (143). However, IL-11 action is likely to be blunted due to the observation that the IL-11 receptor is markedly downregulated in OA chondrocytes (Im et al., unpublished data).

IL-13 downregulates MMP-13 expression in OA chondrocytes (144). Combined with IL-4, IL13 abolishes IL-17 expression in RA synovial tissue (145). A more detailed study revealed that IL-13 represses IL-1 $\beta, T N F-\alpha$, and MMP-3, and simultaneously induces IL-1ra (146). IL-13, as well as IL-4 and IL-10, reduces TNF-a-induced PGE2 release and cyclooxygenase 2 (COX-2) in OA synovial fibroblasts (147). Similar to IL-4, IL-13 also inhibits synoviocyte apoptotic events (133). Nonetheless, IL-13 levels were found to be low in OA tissues (148). Whether IL-13 holds significance to OA pathogenesis needs to be further determined, especially in animal models.

\subsubsection{TGF- $\beta$ /BMP Superfamily}

The TGF- $\beta$ superfamily is composed of over 35 structurally-related members, with the majority of these members playing fundamental roles in development and homeostasis. In articular cartilage, three members of the TGF- $\beta$ superfamily have been shown to play a significant role in cartilage homeostasis: TGF- $\beta$, BMP-2, and BMP-7. BMPs are structurally related to the transforming growth factor- $\beta$ (TGF- $\beta$ ) superfamily and have wide-ranging biological activities, including the regulation of cellular proliferation, apoptosis, differentiation and migration, embryonic development and the maintenance of tissue homeostasis during adult life (149-151). It is now clear that they are expressed in a variety of tissues including adult articular cartilage.

\subsubsection{TGF- $\beta$}

Several studies demonstrate an anabolic role of TGF- $\beta$ in articular cartilage. TGF- $\beta$ has been shown to upregulate chondrocyte synthetic activity and suppress the catabolic activity of IL$1(152,153)$. In vitro, TGF- $\beta$ stimulates chondrogenesis of synovial lining and bone marrowderived mesenchymal stem cells (154). Additionally, asporin inhibits TGF- $\beta$-mediated stimulation of cartilage matrix genes such as collagen type II and aggrecan, and inhibits accumulation of PGs (155). In both Japanese (155) and Han Chinese (156) populations, patients with an asporin polymorphism demonstrated increased prevelance of arthritic conditions, presumably via inhibition of TGF- $\beta$ expression, suggesting a protective role of TGF- $\beta$ in articular cartilage. These findings were corroborated in knockout mice, as mice deficient for TGF- $\beta$ or Smad3 (downstream mediator of TGF- $\beta$ ) developed cartilage degeneration resembling human OA $(157,158)$. Other studies demonstrate a vital role of TGF- $\beta$ in the suppression of NO and other ROS levels (159), as well as the upregulation of PG synthesis in calf-cartilage explants in a dose-dependent manner $(152,160)$. 
However, the literature also suggests that TGF- $\beta$ demonstrates nondesirable side effects in joint tissues. For example, upon sustained exposure to in the joint, TGF- $\beta$ can actually induce the formation of OA-like tissue pathology via stimulation of osteophyte formation, stimulation of synovial inflammation and fibrosis, and attraction of inflammatory leukocytes to the synovial lining $(152,153,161,162)$. These contradictory findings warrant further investigation, and recent research efforts are focused on downstream receptor usage to help provide further clues (152). Nevertheless, given its deleterious effects not seen in other growth factor-based strategies, TGF- $\beta$ therapy is not presently a viable option for use in articular cartilage repair or regeneration.

\subsubsection{BMP-2}

Several studies have analyzed the role of BMP-2 in cartilage and found promising results. The effect of BMP-2 on mesenchymal stem cells is similar to that of TGF- $\beta$, with increased production of ECM and decreased expression of collage type 1, theoretically suppressing the formation of fibrocartilage $(149,154)$. In vitro analysis reveals that BMP-2 stimulates matrix synthesis and reverses chondrocyte dedifferentiation as indicated by an increase in synthesis of cartilage-specific collagen type II in OA chondrocytes (163). In rabbit knees, BMP-2impregnated collagen sponges implanted into full-thickness cartilage defects enhance cartilage repair compared with empty defects or defects filled with collagen sponge alone, with this effect remaining at one year after implantation (164). Interestingly, however, in an IL-1-induced cartilage degeneration model in mice, BMP-2 stimulated matrix production via increased collagen type II and aggrecan expression (anabolic activity), but also increased aggrecan degradation as well, revealing a possible catabolic or self-regulatory role (165). Further studies are indeed warranted to further elucidate the effects of BMP-2 on cartilage repair.

\subsubsection{BMP-7}

BMP-7 (also known as osteogenic protein-1), another member of the TGF- $\beta$ superfamily, is perhaps the most well-studied anabolic growth factor in cartilage repair. It is expressed in cartilage and exerts potent anabolic effects by stimulating differentiation and metabolic functions of both osteocytes and chondrocytes (166). In bone, a variety of animal models have clearly demonstrated a therapeutic potential of BMP-7 in bone repair applications, paving the way for BMP-7 to be used as the first commercial BMP to be used for bone repair clinically (149). In articular cartilage, BMP-7 has potent anabolic effects by stimulating matrix biosynthesis in both human adult articular chondrocytes (167) and human IVD cells (168).

In vitro, BMP-7 has several anabolic and anti-catabolic effects on articular cartilage. It promotes cell survival and upregulates chondrocyte metabolism (169) and protein synthesis without creating uncontrolled cell proliferation and formation of osteophytes, unlike other chondrogenic growth factors $(149,151)$. In a comparison study examining BMP-2, $-4,-6$, and -7 , as well as cartilage-derived morphogenetic protein (CDMP)-1 (also known as GDF-5, growth differentiation factor-5) and CDMP-2, PG synthesis was stimulated to a greater extent by BMP-2 and -4 , and the most significant upregulation after stimulation with BMP-7 (150). Importantly, its actions in cartilage are age-independent as BMP-7 induced similar anabolic responses in normal and OA chondrocytes from both young and old donors without inducing chondrocyte hypertrophy or changes in phenotype (151, 170, 171). Chubinskaya and colleagues have revealed that the anabolic effect of BMP-7 extends beyond 
stimulation of cartilage ECM proteins and their receptors, but also modulates the expression of various anabolic growth factors as well (IGF-1, TGF- $\beta /$ BMPs) (151). In addition to its anabolic capacity, BMP-7 effectively counteracts chondrocyte catabolism, revealing a potent anti-catabolic effect in human articular cartilage. BMP-7 inhibits the expression of proinflammatory cytokines (IL-1 and IL-6), inhibits endogenous expression of cytokines (ie. IL6, IL-8, IL-11) and their downstream signaling molecules (receptors, transcription factors, and mitogen-activated kinases), and blocks both a baseline and cytokine-induced expression of MMP-1 and MMP-13 (151). BMP-7 has also been shown to enhance the gene expression of the anabolic molecule tissue inhibitor of metalloproteinase (TIMP) in normal and OA chondrocytes (151), and acts synergistically with the anabolic growth actors IGF-1 (169) and TGF- $\beta$ (172).

Data from animal studies reveal that BMP-7 clearly has therapeutic potential for cartilage repair. In a large chondral defect study in sheep cartilage, BMP-7 was shown to induce significant cartilage repair in a model where no repair takes place in the controls (173). Studies evaluating models of OA, however, are less numerous, but BMP-7 has been shown to prevent development of damage and in some models reverse the damage (151). Finally, although BMP-7 is highly effective at stimulating bone repair, it does not appear to lead to osteophyte formation when administered into a joint, nor does it stimulate uncontrolled fibroblast proliferation (leading to fibrosis) (149). Studies have demonstrated that recombinant BMP-7 use has a relatively safe profile with few side effects in rabbits, dogs, goats and sheep. Overall, the data clearly indicate that BMP-7 has an important role in cartilage, both in normal homeostasis and in repair, but several unknowns continue to exist, such as concentration, dosing, the use of scaffolds, methods of administration, and possibly combinations with other factors.

\subsubsection{IGF-1}

IGF-1 is a single chain polypeptide that is structurally similar to insulin, a key growth factor that enhances PG synthesis in articular cartilage (174). Much like BMP-7, IGF-1 has a promising future in the field of cartilage repair and regeneration therapy. In vitro, IGF-1 induces anabolic and anti-catabolic effects in normal articular cartilage from a variety of species $(53,175)$. In vivo studies support in vitro findings, as IGF-1 deficiency in rats leads to the development of articular cartilage lesions (176). In animal models, IGF-1 enhances repair of extensive cartilage defects and protects synovial membrane tissue from chronic inflammation $(177,178)$. Other studies in spine cartilage demonstrate similar results. Osada et al showed that IGF-1 stimulates PG synthesis in bovine NP cells in serum-free conditions in a dose-dependent manner and proposed an autocrine/paracrine mechanism of action (179). Gruber and colleagues found that the addition of IGF-1 increased cell survival upon experimental induction of apoptosis in spine disc annulus fibrosus cells (180), consistent with the anti-catabolic capacity of IGF-1 in both intervertebral disc (IVD) and articular cartilage tissues.

Despite its potent anabolic and anti-catabolic effects on normal cartilage tissue, however, IGF-1 appears to have a diminished ability to stimulate ECM formation and decrease catabolism with both age $(181,182)$ and OA $(68,149,181)$. There appears to be an uncoupling of IGF-1 responsiveness in OA, as IGF-1 is able to stimulate matrix synthesis but is unable to decrease matrix catabolism (183). Nevertheless, combination growth factor therapy with IGF-1 and BMP-7 results in greater repair potential than either factor alone 
(169), and the effects of combination factor therapy on aged and old cartilage defects have yet to be determined.

\subsubsection{Resveratrol}

The phytoestrogen resveratrol (trans-3,4',5-trihydroxystilbene; RSV) is a natural polyphenol compound found in peanuts, cranberries, and the skin of red grapes, and is thought to be one of the compounds responsible for the health benefits of moderate red wine consumption $(184,185)$. The anti-inflammatory, anti-oxidant, cardioprotective, and antitumor properties of RSV have been well-documented in a variety of tissues (186-194), and recent studies have begun to analyze the effects of RSV on cartilage homeostasis. Elmali et al reported a significant protective effect of RSV injections on articular cartilage degradation in rabbit models for OA and RA via histological analysis in vivo $(195,196)$. In human articular chondrocytes, Shakibaei (197) and Czaki (198) have elucidated both anti-apoptotic and antiinflammatory regulatory mechanisms mediated by RSV. In our laboratory, we have demonstrated potent anabolic and anti-catabolic potential of RSV in bovine spine nucleus pulposus IVD tissue (199) and human adult articular chondrocytes (Im et al., unpublished data) via inhibition of matrix-degrading enzyme expression at the transcriptional and translational level. Further, combination therapy of RSV with BMP-7 induces synergistic effects on PG accumulation, and RSV reverses the catabolic effects of FGF-2 and IL-1 on matrix-degrading enzyme expression, PG accumulation, and the expression of factors (iNOS, IL-1, IL-6) associated with oxidative stress and inflammatory states (199). Future studies are needed to assess the appropriate dose, route of administration, and downstream effects of RSV, as well as elucidate its role in old or degenerative cartilage in vivo. Nevertheless, these findings reveal considerable promise for use of RSV as a unique biological therapy for treatment of cartilage degenerative diseases in the future.

\subsubsection{Lactoferricin}

Bovine lactoferricin (LfcinB) is a 25-amino acid cationic peptide with an amphipatic, antiparallel $\beta$-sheet structure that is obtained by acid-pepsin hydrolysis of the $\mathrm{N}$-terminal region of lactoferrin (Lf) found in cow's milk $(200,201)$. It exerts more potent biological effects than equimolar amounts of Lf, is cell membrane-permeable, and interacts electrostatically with negatively-charged matrix and cell surface glycosaminoglycans (GAGs), heparin and chondroitin sulfate $(200,201)$. The anti-inflammatory, anti-viral, anti-bacterial, anti-oxidant, anti-pain, and anti-cancer properties of LfcinB have been reported in a variety of tissues $(202,203)$. The natural anti-oxidative effect of LfcinB has also been reported, suggesting a possible chondroprotective biological role in articular cartilage (204), and several recent studies have attempted to elucidate the role of LfcinB in musculoskeletal disease. In a mouse collagen-induced and septic arthritis model, periarticular injection of human Lf substantially suppresses local inflammation (205). Further, in a rat adjuvant arthritis model, oral administration of bovine Lf suppresses the development of arthritis and hyperalgesia in the adjuvant-injected paw, suggesting Lf has preventative and therapeutic effects on the adjuvant-induced inflammation and pain (206). Human iron-free Lf delays the apoptosis of neutrophils isolated from synovial fluid of patients with established rheumatoid arthritis (207). Lf was also identified as a novel bone growth factor, as local injection of Lf above the hemicalvaria of adult mice in vivo results in substantial increases in the dynamic histomorphometric indices of bone formation and bone area (208). 
Previously in our laboratory, LfcinB was found to exert potent anabolic and anti-catabolic effects in bovine nucleus pulposus matrix homeostasis in the IVD, similar to RSV (209). Similar to the IVD, we also found similar anabolic and anti-catabolic effects of LfcinB in human articular cartilage (Im et al, unpublished data). LfcinB reverses the catabolic effects of FGF-2 and IL-1 on matrix-degrading enzyme production, PG accumulation, and expression of factors associated with oxidative stress and inflammation, suggesting the promise of LfcinB as an anti-catabolic and anti-inflammatory molecule in human articular cartilage. Further, LfcinB abolishes the expression of iNOS, increases the expression of SOD1 , and antagonizes the catabolic effects mediated by bFGF and IL-1 on iNOS and SOD-1 expression, suggesting an anti-oxidative role of LfcinB in cartilage. Taken together, much like RSV, LfcinB may play an important role in prevention and treatment of diseases such as OA. Nevertheless, caution must be advised as further studies are warranted to determine, among other things, possible detrimental effects of its use in vivo.

\section{Pain modulators in $O A$}

Clinically, pain is the most prominent and disabling symptom of OA, and arthritic pain is associated with inferior functional outcomes and reduced quality of life compared with a range of other chronic conditions (210). Like other chronic pain conditions, OA pain is a complex integration of sensory, affective and cognitive processes that involves a variety of abnormal cellular mechanisms at both peripheral (joints) and central (spinal and supraspinal) levels of the nervous system. For the development of new therapies aimed at pain relief, a thorough understanding of the pathological mechanisms eliciting pain in OA is required. Unfortunately, many of these mechanisms remain elusive because the primary site of pathology (i.e., articular cartilage) does not have neuronal pain receptors that can directly detect tissue injury due to mechanical damage. The process by which painful mechanical stimuli from arthritic joints are converted into electrical signals that propagate along sensory nerves to the central nervous system remains to be fully explored.

Nociceptors are located throughout the joint in tissues peripheral to cartilage, including the joint capsule, ligaments, periosteum and subchondral bone. Joint cartilage and synovial injury influences peripheral afferent and dorsal root ganglion (DRG) neurons and sensitizes symptomatic pain perception through the dynamic interactions between neuropathic pathways and OA tissues. Nociceptive input from the joint is processed via different spinal cord pathways, and inflammation may potentially reduce the threshold for pain. The relative contribution of these processes into peripheral and central pathways appears to be strongly segmented (211), with intra-articular anesthetic studies in hip and knee OA suggesting a peripheral drive to pain in approximately $60 \%$ to $80 \%$ of patients, depending on the affected joint (212). In some individuals, however, central mechanisms such as dysfunction of descending inhibitory control or altered cortical processing of noxious information, may play a greater role (213). Therefore, research and pharmacotherapy for OA pain may be separated into two broad classes: central sensitization and peripheral sensitization, both leading to one final outcome: pain in a patient with OA.

A detailed overview of the multiple, complex pathways associated with OA pain, particularly relating to central sensitization mechanisms, is outside the scope of this chapter. For example, current targets of pharmacotherapy for OA pain are numerous and include opioids, kinins, cannabinoids, and their respective receptors, in addition to adrenergic receptors, glutamate receptors, specific ion channels, and neurotrophins. The literature is 
replete with data on the alteration of pain pathways via inhibition of both central and peripheral processes (211). Here, we will focus on select pro-inflammatory cytokines and mediators previously discussed in this chapter, and report their known roles in pain processing. Our laboratory and others have mechanistically linked OA to pathological changes in the metabolism of ECM proteins and inflammatory states that may be controlled by epigenetic, epigenomic, and systemic processes involved in pain processing $(5,9,89,93$, 94, 199, 214, 215).

\subsection{Cytokines}

Inflammatory stimuli initiate a cascade of events, including the production of TNF-a, interleukins, chemokines, sympathetic amines, substance $\mathrm{P}$, leukotrienes and prostaglandins, each demonstrating a complex interplay with other mediators to induce pain $(211,216)$. Cytokines stimulate hyperalgesia by a number of direct and indirect actions. Sensitization of primary afferent fibers for mechanical stimuli is thought to be induced by inflammatory mediators. IL-1 $\beta$ activates nociceptors directly via intracellular kinase activation, but it may also induce indirect nociceptor sensitization via the production of kinins and prostanoids (217).

IL-6, a well-known pro-inflammatory mediator, has been associated with hyperalgesia and hypersensitivity in articular cartilage (218). As previously discussed, IL-6 plays an important role in the pathogenesis of rheumatoid arthritis, and its concentration is elevated in the serum and synovial fluid of arthritic patients $(219,220)$. Interestingly, primary afferent neurons also respond to IL-6 (221), suggesting an important role of IL-6 in pain propagation in arthritic states.

TNF-a also activates sensory neurons directly via the receptors TNFR1 and TNFR2, and initiates a cascade of inflammatory reactions via the production of IL-1, IL-6 and IL-8 (217, 222). Direct TNF- $\alpha$ application in the periphery induces neuropathic pain, and this pain may be blocked by anti-inflammatory medications such as ibuprofen and celecoxib (223). AntiTNF- $\alpha$ treatment with a TNF antibody produces a prolonged reduction of pain symptoms in OA (224), and neutralization of TNF-a in mice rescues both mechanical hyperalgesia (testing of withdrawal responses in behavioral experiments) and the inflammatory process (225). Taken together, TNF-a induces an algesic effect, at least in part, via both neuronal and inflammatory stimulation. Antagonists to TNF-a, such as etanercept or infliximab, may indeed serve as a potential therapeutic strategy to decrease OA pain clinically (211). Further controlled studies are needed to substantiate these promising preliminary data on TNF inhibitors in OA.

\subsection{Prostanoids and PGE2}

During pro-inflammatory states, numerous prostanoid cyclooxygenase (COX) enzyme products are produced and released, including PGE2, PGD2, PGF2a, thromboxane, and PGI2 (211). These factors serve as the premise for blocking the major synthetic enzymes COX-1 and COX-2 with selective or non-selective COX-inhibitor medications (ie. nonsteroidal anti-inflammatory drugs) (226). Of these mediators, PGE2 is considered to be the major contributor to inflammatory pain in arthritic conditions. PGE2 exerts its effects via a variety of $\mathrm{E}$ prostanoid (EP) receptors (EP1, EP2, EP3, EP4), which are present in both peripheral sensory neurons and the spinal cord (211). Activation of these receptors produces a variety of effects, ranging from calcium influx to cAMP activation or inhibition. 
Peripherally, sensitization of nociceptors by PGE2 is caused by the cAMP-mediated enhancement of sodium currents after ion channel phosphorylation (227). However, in the spinal cord, PGE2 acts via different receptors than peripherally, suggesting further complexity in the prostanoid regulation of pain (228).

In our laboratory, we have assessed the role of PGE2 in human adult articular cartilage homeostasis and its relation to possible pain pathways (58). PGE2 utilizes the EP2 and EP4 receptors downstream to induce its downstream catabolic effects, and PGE2 may mediate pain pathways in articular cartilage via its stimulatory effect on the pain-associated factors IL-6 (218) and iNOS (229). Further, when combined with the catabolic cytokine IL-1, PGE2 synergistically upregulates both IL-6 and iNOS mRNA levels in vitro (58). Similar synergistic results were found with iNOS expression as well. Therefore, the EP2/4 receptor may be an important signaling initiator of the PGE2-signaling cascade and a potential target for therapeutic strategies aimed at preventing progression of arthritic disease and pain in the future.

As opposed to PGE2 EP receptor blockade, an alternative route of PGE2 inhibition is via the blockade of PGE synthase (PGES), a major route of conversion of prostaglandin H2 to PGE2 (211). Two isoforms of the enzyme have been identified, membrane or microsomal associated (mPGES-1) and cytosolic (cPGES/p23), which are linked with COX-2 and COX-1 dependent PGE2 production, respectively (230). Both isoforms are upregulated by inflammatory mediators, and gene deletion studies in mice indicate an important role for mPGES in acute and chronic inflammation and inflammatory pain, revealing a potential target for pain treatment in OA $(211,231)$.

\section{Discussion}

In summary, the literature reveals important roles of catabolic and anabolic growth factors and cytokines in articular cartilage homeostasis and the development of OA. Each factor discussed plays a critical role in cartilage, both in normal homeostasis and in repair. Currently, many of these specific roles remain unknown, but recent efforts have begun to increase our understanding. Catabolic factors include pro-inflammatory mediators (IL-1, IL6, IL-17, TNF-a and PGE2), oxidative mediators (iNOS), glycoproteins (fibronectin, osteonectin, and osteopontin), and even growth factors (FGF-2). In contrast, anabolic mediators include select interleukins, TGF- $\beta$, IGF-1, BMPs (BMP-2 and BMP-7), RSV and LfcinB. Upregulation of catabolic processes and/or downregulation of anabolic processes leads to disruption of equilibrium with subsequent cartilage degradation and $\mathrm{OA}$, and several of these pathways are known to induce pain in OA as well (ie. IL-1, IL-6, NO, TNF-a, PGE2). The goal of biologic therapy is to retard this process via inhibition of catabolic processes and upregulation of anabolic processes with the hope of clinically preserving joint cartilage, thereby slowing or preventing the process of OA.

Despite a tremendous research effort in recent years to elucidate these processes, however, biologic therapy for OA remains experimental in nature, and several unknowns exist. Given the wide array of interactions of growth factors that are necessary for proper cartilage development and homeostasis in vivo, it is unlikely that any single growth factor will lead to complete cartilage repair or affect the arthritic joint clinically, and rather a combination approach will be required (149). Further, appropriate dosing, scaffolds, and routes of administration must be determined before any of these factors plays a role clinically. Nevertheless, this chapter reviews several of the most well-studied biochemical mediators 
involved in OA and provides a framework for the understanding of potential biologic therapies in the treatment of degenerative joint disease in the future.

\section{References}

[1] Lewis PB, McCarty LP, 3rd, Kang RW, Cole BJ. Basic science and treatment options for articular cartilage injuries. J Orthop Sports Phys Ther. 2006;36(10):717-27.

[2] Sandell LJ, Aigner T. Articular cartilage and changes in arthritis. An introduction: cell biology of osteoarthritis. Arthritis Res. 2001;3(2):107-13.

[3] Valverde-Franco G, Binette JS, Li W, Wang H, Chai S, Laflamme F, et al. Defects in articular cartilage metabolism and early arthritis in fibroblast growth factor receptor 3 deficient mice. Hum Mol Genet. 2006;15(11):1783-92.

[4] Nakata K, Ono K, Miyazaki J, Olsen BR, Muragaki Y, Adachi E, et al. Osteoarthritis associated with mild chondrodysplasia in transgenic mice expressing alpha 1(IX) collagen chains with a central deletion. Proc Natl Acad Sci U S A. 1993;90(7):2870-4.

[5] Im HJ, Li X, Muddasani P, Kim GH, Davis F, Rangan J, et al. Basic fibroblast growth factor accelerates matrix degradation via a neuro-endocrine pathway in human adult articular chondrocytes. J Cell Physiol. 2008;215(2):452-63.

[6] Bau B, Gebhard PM, Haag J, Knorr T, Bartnik E, Aigner T. Relative messenger RNA expression profiling of collagenases and aggrecanases in human articular chondrocytes in vivo and in vitro. Arthritis Rheum. 2002;46(10):2648-57.

[7] Liu MH, Sun JS, Tsai SW, Sheu SY, Chen MH. Icariin protects murine chondrocytes from lipopolysaccharide-induced inflammatory responses and extracellular matrix degradation. Nutr Res.30(1):57-65.

[8] Iannone F, Lapadula G. The pathophysiology of osteoarthritis. Aging Clin Exp Res. 2003;15(5):364-72.

[9] Ellman MB, An HS, Muddasani P, Im HJ. Biological impact of the fibroblast growth factor family on articular cartilage and intervertebral disc homeostasis. Gene. 2008;420(1):82-9.

[10] Del Carlo M, Schwartz D, Erickson EA, Loeser RF. Endogenous production of reactive oxygen species is required for stimulation of human articular chondrocyte matrix metalloproteinase production by fibronectin fragments. Free Radic Biol Med. 2007;42(9):1350-8.

[11] Goldring MB, Birkhead J, Sandell LJ, Kimura T, Krane SM. Interleukin 1 suppresses expression of cartilage-specific types II and IX collagens and increases types I and III collagens in human chondrocytes. J Clin Invest. 1988;82(6):2026-37.

[12] Lefebvre V, Peeters-Joris C, Vaes G. Modulation by interleukin 1 and tumor necrosis factor alpha of production of collagenase, tissue inhibitor of metalloproteinases and collagen types in differentiated and dedifferentiated articular chondrocytes. Biochim Biophys Acta. 1990;1052(3):366-78.

[13] Richardson DW, Dodge GR. Effects of interleukin-1beta and tumor necrosis factoralpha on expression of matrix-related genes by cultured equine articular chondrocytes. Am J Vet Res. 2000;61(6):624-30.

[14] Goldring MB. Osteoarthritis and cartilage: the role of cytokines. Curr Rheumatol Rep. 2000;2(6):459-65. 
[15] Kapoor M, Martel-Pelletier J, Lajeunesse D, Pelletier JP, Fahmi H. Role of proinflammatory cytokines in the pathophysiology of osteoarthritis. Nat Rev Rheumatol.7(1):33-42.

[16] Benito MJ, Veale DJ, FitzGerald O, van den Berg WB, Bresnihan B. Synovial tissue inflammation in early and late osteoarthritis. Ann Rheum Dis. 2005;64(9):1263-7.

[17] Smith MD, Triantafillou S, Parker A, Youssef PP, Coleman M. Synovial membrane inflammation and cytokine production in patients with early osteoarthritis. J Rheumatol. 1997;24(2):365-71.

[18] Martel-Pelletier J, McCollum R, DiBattista J, Faure MP, Chin JA, Fournier S, et al. The interleukin-1 receptor in normal and osteoarthritic human articular chondrocytes. Identification as the type I receptor and analysis of binding kinetics and biologic function. Arthritis Rheum. 1992;35(5):530-40.

[19] Evans CH, Gouze JN, Gouze E, Robbins PD, Ghivizzani SC. Osteoarthritis gene therapy. Gene Ther. 2004;11(4):379-89.

[20] Guerne PA, Carson DA, Lotz M. IL-6 production by human articular chondrocytes. Modulation of its synthesis by cytokines, growth factors, and hormones in vitro. J Immunol. 1990;144(2):499-505.

[21] Doss F, Menard J, Hauschild M, Kreutzer HJ, Mittlmeier T, Muller-Steinhardt M, et al. Elevated IL-6 levels in the synovial fluid of osteoarthritis patients stem from plasma cells. Scand J Rheumatol. 2007;36(2):136-9.

[22] Moktar NM, Yusof HM, Yahaya NH, Muhamad R, Das S. The transcript level of interleukin-6 in the cartilage of idiopathic osteoarthritis of knee. Clin Ter.161(1):258.

[23] Guerne PA, Desgeorges A, Jaspar JM, Relic B, Peter R, Hoffmeyer P, et al. Effects of IL6 and its soluble receptor on proteoglycan synthesis and NO release by human articular chondrocytes: comparison with IL-1. Modulation by dexamethasone. Matrix Biol. 1999;18(3):253-60.

[24] Jikko A, Wakisaka T, Iwamoto M, Hiranuma H, Kato Y, Maeda T, et al. Effects of interleukin-6 on proliferation and proteoglycan metabolism in articular chondrocyte cultures. Cell Biol Int. 1998;22(9-10):615-21.

[25] Flannery CR, Little CB, Hughes CE, Curtis CL, Caterson B, Jones SA. IL-6 and its soluble receptor augment aggrecanase-mediated proteoglycan catabolism in articular cartilage. Matrix Biol. 2000;19(6):549-53.

[26] Poree B, Kypriotou M, Chadjichristos C, Beauchef G, Renard E, Legendre F, et al. Interleukin-6 (IL-6) and/or soluble IL-6 receptor down-regulation of human type II collagen gene expression in articular chondrocytes requires a decrease of Sp1.Sp3 ratio and of the binding activity of both factors to the COL2A1 promoter. J Biol Chem. 2008;283(8):4850-65.

[27] Mathy-Hartert M, Hogge L, Sanchez C, Deby-Dupont G, Crielaard JM, Henrotin Y. Interleukin-1beta and interleukin-6 disturb the antioxidant enzyme system in bovine chondrocytes: a possible explanation for oxidative stress generation. Osteoarthritis Cartilage. 2008;16(7):756-63. 
[28] de Hooge AS, van de Loo FA, Bennink MB, Arntz OJ, de Hooge P, van den Berg WB. Male IL-6 gene knock out mice developed more advanced osteoarthritis upon aging. Osteoarthritis Cartilage. 2005;13(1):66-73.

[29] Ryu JH, Yang S, Shin Y, Rhee J, Chun CH, Chun JS. Interleukin 6 plays an essential role in hypoxia-inducible factor-2alpha-induced experimental osteoarthritic cartilage destruction in mice. Arthritis Rheum.

[30] Distel E, Cadoudal T, Durant S, Poignard A, Chevalier X, Benelli C. The infrapatellar fat pad in knee osteoarthritis: an important source of interleukin-6 and its soluble receptor. Arthritis Rheum. 2009;60(11):3374-7.

[31] Sylvester J, Liacini A, Li WQ, Zafarullah M. Interleukin-17 signal transduction pathways implicated in inducing matrix metalloproteinase-3, -13 and aggrecanase1 genes in articular chondrocytes. Cell Signal. 2004;16(4):469-76.

[32] Benderdour M, Tardif G, Pelletier JP, Di Battista JA, Reboul P, Ranger P, et al. Interleukin 17 (IL-17) induces collagenase-3 production in human osteoarthritic chondrocytes via AP-1 dependent activation: differential activation of AP-1 members by IL-17 and IL-1beta. J Rheumatol. 2002;29(6):1262-72.

[33] Pacquelet S, Presle N, Boileau C, Dumond H, Netter P, Martel-Pelletier J, et al. Interleukin 17, a nitric oxide-producing cytokine with a peroxynitrite-independent inhibitory effect on proteoglycan synthesis. J Rheumatol. 2002;29(12):2602-10.

[34] Honorati MC, Neri S, Cattini L, Facchini A. Interleukin-17, a regulator of angiogenic factor release by synovial fibroblasts. Osteoarthritis Cartilage. 2006;14(4):345-52.

[35] Attur MG, Patel RN, Abramson SB, Amin AR. Interleukin-17 up-regulation of nitric oxide production in human osteoarthritis cartilage. Arthritis Rheum. 1997;40(6):1050-3.

[36] Koshy PJ, Henderson N, Logan C, Life PF, Cawston TE, Rowan AD. Interleukin 17 induces cartilage collagen breakdown: novel synergistic effects in combination with proinflammatory cytokines. Ann Rheum Dis. 2002;61(8):704-13.

[37] Martel-Pelletier J, Mineau F, Jovanovic D, Di Battista JA, Pelletier JP. Mitogen-activated protein kinase and nuclear factor kappaB together regulate interleukin-17-induced nitric oxide production in human osteoarthritic chondrocytes: possible role of transactivating factor mitogen-activated protein kinase-activated proten kinase (MAPKAPK). Arthritis Rheum. 1999;42(11):2399-409.

[38] LeGrand A, Fermor B, Fink C, Pisetsky DS, Weinberg JB, Vail TP, et al. Interleukin-1, tumor necrosis factor alpha, and interleukin-17 synergistically up-regulate nitric oxide and prostaglandin E2 production in explants of human osteoarthritic knee menisci. Arthritis Rheum. 2001;44(9):2078-83.

[39] Shalom-Barak T, Quach J, Lotz M. Interleukin-17-induced gene expression in articular chondrocytes is associated with activation of mitogen-activated protein kinases and NF-kappaB. J Biol Chem. 1998;273(42):27467-73.

[40] Honorati MC, Bovara M, Cattini L, Piacentini A, Facchini A. Contribution of interleukin 17 to human cartilage degradation and synovial inflammation in osteoarthritis. Osteoarthritis Cartilage. 2002;10(10):799-807. 
[41] Jovanovic DV, Di Battista JA, Martel-Pelletier J, Jolicoeur FC, He Y, Zhang M, et al. IL17 stimulates the production and expression of proinflammatory cytokines, IL-beta and TNF-alpha, by human macrophages. J Immunol. 1998;160(7):3513-21.

[42] Koenders MI, Marijnissen RJ, Devesa I, Lubberts E, Joosten LA, Roth J, et al. TNF / IL17 interplay induces S100A8, IL-1beta, and MMPs, and drives irreversible cartilage destruction In Vivo: Rationale for combination treatment during arthritis. Arthritis Rheum.

[43] Nakae S, Nambu A, Sudo K, Iwakura Y. Suppression of immune induction of collageninduced arthritis in IL-17-deficient mice. J Immunol. 2003;171(11):6173-7.

[44] Westacott CI, Atkins RM, Dieppe PA, Elson CJ. Tumor necrosis factor-alpha receptor expression on chondrocytes isolated from human articular cartilage. J Rheumatol. 1994;21(9):1710-5.

[45] Webb GR, Westacott CI, Elson CJ. Osteoarthritic synovial fluid and synovium supernatants up-regulate tumor necrosis factor receptors on human articular chondrocytes. Osteoarthritis Cartilage. 1998;6(3):167-76.

[46] Marks PH, Donaldson ML. Inflammatory cytokine profiles associated with chondral damage in the anterior cruciate ligament-deficient knee. Arthroscopy. 2005;21(11):1342-7.

[47] Shinmei M, Masuda K, Kikuchi T, Shimomura Y, Okada Y. Production of cytokines by chondrocytes and its role in proteoglycan degradation. J Rheumatol Suppl. 1991;27:89-91.

[48] Malfait AM, Verbruggen G, Veys EM, Lambert J, De Ridder L, Cornelissen M. Comparative and combined effects of interleukin 6, interleukin 1 beta, and tumor necrosis factor alpha on proteoglycan metabolism of human articular chondrocytes cultured in agarose. J Rheumatol. 1994;21(2):314-20.

[49] Steenvoorden MM, Bank RA, Ronday HK, Toes RE, Huizinga TW, DeGroot J. Fibroblast-like synoviocyte-chondrocyte interaction in cartilage degradation. Clin Exp Rheumatol. 2007;25(2):239-45.

[50] Muller RD, John T, Kohl B, Oberholzer A, Gust T, Hostmann A, et al. IL-10 overexpression differentially affects cartilage matrix gene expression in response to TNF-alpha in human articular chondrocytes in vitro. Cytokine. 2008;44(3):377-85.

[51] Ray A, Bal BS, Ray BK. Transcriptional induction of matrix metalloproteinase-9 in the chondrocyte and synoviocyte cells is regulated via a novel mechanism: evidence for functional cooperation between serum amyloid A-activating factor-1 and AP-1. J Immunol. 2005;175(6):4039-48.

[52] Shinmei M, Masuda K, Kikuchi T, Shimomura Y. The role of cytokines in chondrocyte mediated cartilage degradation. J Rheumatol Suppl. 1989;18:32-4.

[53] Tyler JA. Insulin-like growth factor 1 can decrease degradation and promote synthesis of proteoglycan in cartilage exposed to cytokines. Biochem J. 1989;260(2):543-8.

[54] Polzer K, Schett G, Zwerina J. The lonely death: chondrocyte apoptosis in TNF-induced arthritis. Autoimmunity. 2007;40(4):333-6.

[55] Lee SW, Song YS, Lee SY, Yoon YG, Lee SH, Park BS, et al. Downregulation of Protein Kinase CK2 Activity Facilitates Tumor Necrosis Factor-alpha-Mediated Chondrocyte Death through Apoptosis and Autophagy. PLoS One.6(4):e19163. 
[56] Mitrovic D, Lippiello L, Gruson F, Aprile F, Mankin HJ. Effects of various prostanoids on the in vitro metabolism of bovine articular chondrocytes. Prostaglandins. 1981;22(3):499-511.

[57] Amin AR, Dave M, Attur M, Abramson SB. COX-2, NO, and cartilage damage and repair. Curr Rheumatol Rep. 2000;2(6):447-53.

[58] Li X, Ellman M, Muddasani P, Wang JH, Cs-Szabo G, van Wijnen AJ, et al. Prostaglandin E2 and its cognate EP receptors control human adult articular cartilage homeostasis and are linked to the pathophysiology of osteoarthritis. Arthritis Rheum. 2009;60(2):513-23.

[59] Attur M, Al-Mussawir HE, Patel J, Kitay A, Dave M, Palmer G, et al. Prostaglandin E2 exerts catabolic effects in osteoarthritis cartilage: evidence for signaling via the EP4 receptor. J Immunol. 2008;181(7):5082-8.

[60] Otsuka S, Aoyama T, Furu M, Ito K, Jin Y, Nasu A, et al. PGE2 signal via EP2 receptors evoked by a selective agonist enhances regeneration of injured articular cartilage. Osteoarthritis Cartilage. 2009;17(4):529-38.

[61] Miwa M, Saura R, Hirata S, Hayashi Y, Mizuno K, Itoh H. Induction of apoptosis in bovine articular chondrocyte by prostaglandin $\mathrm{E}(2)$ through cAMP-dependent pathway. Osteoarthritis Cartilage. 2000;8(1):17-24.

[62] Notoya K, Jovanovic DV, Reboul P, Martel-Pelletier J, Mineau F, Pelletier JP. The induction of cell death in human osteoarthritis chondrocytes by nitric oxide is related to the production of prostaglandin E2 via the induction of cyclooxygenase2. J Immunol. 2000;165(6):3402-10.

[63] Campbell IK, Piccoli DS, Hamilton JA. Stimulation of human chondrocyte prostaglandin E2 production by recombinant human interleukin-1 and tumour necrosis factor. Biochim Biophys Acta. 1990;1051(3):310-8.

[64] Tawara T, Shingu M, Nobunaga M, Naono T. Effects of recombinant human IL-1 beta on production of prostaglandin E2, leukotriene B4, NAG, and superoxide by human synovial cells and chondrocytes. Inflammation. 1991;15(2):145-57.

[65] Verbruggen G, Veys EM, Malfait AM, De Clercq L, Van den Bosch F, de Vlam K. Influence of human recombinant interleukin-1 beta on human articular cartilage. Mitotic activity and proteoglycan metabolism. Clin Exp Rheumatol. 1991;9(5):481-8.

[66] Gosset M, Pigenet A, Salvat C, Berenbaum F, Jacques C. Inhibition of matrix metalloproteinase-3 and -13 synthesis induced by IL-1beta in chondrocytes from mice lacking microsomal prostaglandin E synthase-1. J Immunol.185(10):6244-52.

[67] Di Battista JA, Dore S, Martel-Pelletier J, Pelletier JP. Prostaglandin E2 stimulates incorporation of proline into collagenase digestible proteins in human articular chondrocytes: identification of an effector autocrine loop involving insulin-like growth factor I. Mol Cell Endocrinol. 1996;123(1):27-35.

[68] Dore S, Pelletier JP, DiBattista JA, Tardif G, Brazeau P, Martel-Pelletier J. Human osteoarthritic chondrocytes possess an increased number of insulin-like growth factor 1 binding sites but are unresponsive to its stimulation. Possible role of IGF-1binding proteins. Arthritis Rheum. 1994;37(2):253-63. 
[69] Taskiran D, Stefanovic-Racic M, Georgescu H, Evans C. Nitric oxide mediates suppression of cartilage proteoglycan synthesis by interleukin-1. Biochem Biophys Res Commun. 1994;200(1):142-8.

[70] Hauselmann HJ, Oppliger L, Michel BA, Stefanovic-Racic M, Evans CH. Nitric oxide and proteoglycan biosynthesis by human articular chondrocytes in alginate culture. FEBS Lett. 1994;352(3):361-4.

[71] Vuolteenaho K, Moilanen T, Knowles RG, Moilanen E. The role of nitric oxide in osteoarthritis. Scand J Rheumatol. 2007;36(4):247-58.

[72] Tamura T, Nakanishi T, Kimura Y, Hattori T, Sasaki K, Norimatsu H, et al. Nitric oxide mediates interleukin-1-induced matrix degradation and basic fibroblast growth factor release in cultured rabbit articular chondrocytes: a possible mechanism of pathological neovascularization in arthritis. Endocrinology. 1996;137(9):3729-37.

[73] Abramson SB. Nitric oxide in inflammation and pain associated with osteoarthritis. Arthritis Res Ther. 2008;10 Suppl 2:S2.

[74] Studer R, Jaffurs D, Stefanovic-Racic M, Robbins PD, Evans CH. Nitric oxide in osteoarthritis. Osteoarthritis Cartilage. 1999;7(4):377-9.

[75] Borderie D, Hilliquin P, Hernvann A, Lemarechal H, Menkes CJ, Ekindjian OG. Apoptosis induced by nitric oxide is associated with nuclear p53 protein expression in cultured osteoarthritic synoviocytes. Osteoarthritis Cartilage. 1999;7(2):203-13.

[76] Del Carlo M, Jr., Loeser RF. Nitric oxide-mediated chondrocyte cell death requires the generation of additional reactive oxygen species. Arthritis Rheum. 2002;46(2):394403.

[77] Studer RK, Levicoff E, Georgescu H, Miller L, Jaffurs D, Evans CH. Nitric oxide inhibits chondrocyte response to IGF-I: inhibition of IGF-IRbeta tyrosine phosphorylation. Am J Physiol Cell Physiol. 2000;279(4):C961-9.

[78] van der Kraan PM, Vitters EL, van Beuningen HM, van de Loo FA, van den Berg WB. Role of nitric oxide in the inhibition of BMP-2-mediated stimulation of proteoglycan synthesis in articular cartilage. Osteoarthritis Cartilage. 2000;8(2):82-6.

[79] Amin AR, Di Cesare PE, Vyas P, Attur M, Tzeng E, Billiar TR, et al. The expression and regulation of nitric oxide synthase in human osteoarthritis-affected chondrocytes: evidence for up-regulated neuronal nitric oxide synthase. J Exp Med. 1995;182(6):2097-102.

[80] Melchiorri C, Meliconi R, Frizziero L, Silvestri T, Pulsatelli L, Mazzetti I, et al. Enhanced and coordinated in vivo expression of inflammatory cytokines and nitric oxide synthase by chondrocytes from patients with osteoarthritis. Arthritis Rheum. 1998;41(12):2165-74.

[81] Amin AR, Attur M, Abramson SB. Nitric oxide synthase and cyclooxygenases: distribution, regulation, and intervention in arthritis. Curr Opin Rheumatol. 1999;11(3):202-9.

[82] Vuolteenaho K, Moilanen T, Hamalainen M, Moilanen E. Effects of TNFalphaantagonists on nitric oxide production in human cartilage. Osteoarthritis Cartilage. 2002;10(4):327-32.

[83] Jarvinen K, Vuolteenaho K, Nieminen R, Moilanen T, Knowles RG, Moilanen E. Selective iNOS inhibitor 1400W enhances anti-catabolic IL-10 and reduces 
destructive MMP-10 in OA cartilage. Survey of the effects of $1400 \mathrm{~W}$ on inflammatory mediators produced by OA cartilage as detected by protein antibody array. Clin Exp Rheumatol. 2008;26(2):275-82.

[84] Huang CY, Hung LF, Liang CC, Ho LJ. COX-2 and iNOS are critical in advanced glycation end product-activated chondrocytes in vitro. Eur J Clin Invest. 2009;39(5):417-28.

[85] Vuolteenaho K, Koskinen A, Kukkonen M, Nieminen R, Paivarinta U, Moilanen T, et al. Leptin enhances synthesis of proinflammatory mediators in human osteoarthritic cartilage--mediator role of NO in leptin-induced PGE2, IL-6, and IL-8 production. Mediators Inflamm. 2009;2009:345838.

[86] Pelletier JP, Jovanovic D, Fernandes JC, Manning P, Connor JR, Currie MG, et al. Reduced progression of experimental osteoarthritis in vivo by selective inhibition of inducible nitric oxide synthase. Arthritis Rheum. 1998;41(7):1275-86.

[87] Presle N, Cipolletta C, Jouzeau JY, Abid A, Netter P, Terlain B. Cartilage protection by nitric oxide synthase inhibitors after intraarticular injection of interleukin-1beta in rats. Arthritis Rheum. 1999;42(10):2094-102.

[88] Sah RL, Trippel SB, Grodzinsky AJ. Differential effects of serum, insulin-like growth factor-I, and fibroblast growth factor-2 on the maintenance of cartilage physical properties during long-term culture. J Orthop Res. 1996;14(1):44-52.

[89] Loeser RF, Chubinskaya S, Pacione C, Im HJ. Basic fibroblast growth factor inhibits the anabolic activity of insulin-like growth factor 1 and osteogenic protein 1 in adult human articular chondrocytes. Arthritis Rheum. 2005;52(12):3910-7.

[90] Schmal H, Zwingmann J, Fehrenbach M, Finkenzeller G, Stark GB, Sudkamp NP, et al. bFGF influences human articular chondrocyte differentiation. Cytotherapy. 2007;9(2):184-93.

[91] Stewart K, Pabbruwe M, Dickinson S, Sims T, Hollander AP, Chaudhuri JB. The effect of growth factor treatment on meniscal chondrocyte proliferation and differentiation on polyglycolic acid scaffolds. Tissue Eng. 2007;13(2):271-80.

[92] Sonal D. Prevention of IGF-1 and TGFbeta stimulated type II collagen and decorin expression by bFGF and identification of IGF-1 mRNA transcripts in articular chondrocytes. Matrix Biol. 2001;20(4):233-42.

[93] Muddasani P, Norman JC, Ellman M, van Wijnen AJ, Im HJ. Basic fibroblast growth factor activates the MAPK and NFkappaB pathways that converge on Elk-1 to control production of matrix metalloproteinase-13 by human adult articular chondrocytes. J Biol Chem. 2007;282(43):31409-21.

[94] Im HJ, Muddasani P, Natarajan V, Schmid TM, Block JA, Davis F, et al. Basic fibroblast growth factor stimulates matrix metalloproteinase-13 via the molecular cross-talk between the mitogen-activated protein kinases and protein kinase Cdelta pathways in human adult articular chondrocytes. J Biol Chem. 2007;282(15):11110-21.

[95] Yan D, Muddasani P, Cool SM, van Wijnen AJ, Mikecz K, Murphy G, et al. Fibroblast Growth Factor Receptor 1 Is Principally Responsible For Fibroblast Growth Factor 2-Induced Catabolic Activities In Human Articular Chondrocytes. Arthritis Res Ther. 2011:In press. 
[96] Sawaji Y, Hynes J, Vincent T, Saklatvala J. Fibroblast growth factor 2 inhibits induction of aggrecanase activity in human articular cartilage. Arthritis Rheum. 2008;58(11):3498-509.

[97] Chia SL, Sawaji Y, Burleigh A, McLean C, Inglis J, Saklatvala J, et al. Fibroblast growth factor 2 is an intrinsic chondroprotective agent that suppresses ADAMTS- 5 and delays cartilage degradation in murine osteoarthritis. Arthritis Rheum. 2009;60(7):2019-27.

[98] Yasuda T. Cartilage destruction by matrix degradation products. Mod Rheumatol. 2006;16(4):197-205.

[99] Homandberg GA, Wen C, Hui F. Cartilage damaging activities of fibronectin fragments derived from cartilage and synovial fluid. Osteoarthritis Cartilage. 1998;6(4):231-44.

[100] Jones KL, Brown M, Ali SY, Brown RA. An immunohistochemical study of fibronectin in human osteoarthritic and disease free articular cartilage. Ann Rheum Dis. 1987;46(11):809-15.

[101] Zack MD, Malfait AM, Skepner AP, Yates MP, Griggs DW, Hall T, et al. ADAM-8 isolated from human osteoarthritic chondrocytes cleaves fibronectin at Ala(271). Arthritis Rheum. 2009;60(9):2704-13.

[102] Xie DL, Meyers R, Homandberg GA. Fibronectin fragments in osteoarthritic synovial fluid. J Rheumatol. 1992;19(9):1448-52.

[103] Chevalier X, Groult N, Emod I, Planchenault T. Proteoglycan-degrading activity associated with the $40 \mathrm{kDa}$ collagen-binding fragment of fibronectin. $\mathrm{Br} \mathrm{J}$ Rheumatol. 1996;35(6):506-14.

[104] Yasuda T, Poole AR. A fibronectin fragment induces type II collagen degradation by collagenase through an interleukin-1-mediated pathway. Arthritis Rheum. 2002;46(1):138-48.

[105] Johnson A, Smith R, Saxne T, Hickery M, Heinegard D. Fibronectin fragments cause release and degradation of collagen-binding molecules from equine explant cultures. Osteoarthritis Cartilage. 2004;12(2):149-59.

[106] Kang Y, Koepp H, Cole AA, Kuettner KE, Homandberg GA. Cultured human ankle and knee cartilage differ in susceptibility to damage mediated by fibronectin fragments. J Orthop Res. 1998;16(5):551-6.

[107] Long D, Blake S, Song XY, Lark M, Loeser RF. Human articular chondrocytes produce IL-7 and respond to IL-7 with increased production of matrix metalloproteinase-13. Arthritis Res Ther. 2008;10(1):R23.

[108] Saito S, Yamaji N, Yasunaga K, Saito T, Matsumoto S, Katoh M, et al. The fibronectin extra domain A activates matrix metalloproteinase gene expression by an interleukin-1-dependent mechanism. J Biol Chem. 1999;274(43):30756-63.

[109] Stanton H, Ung L, Fosang AJ. The $45 \mathrm{kDa}$ collagen-binding fragment of fibronectin induces matrix metalloproteinase-13 synthesis by chondrocytes and aggrecan degradation by aggrecanases. Biochem J. 2002;364(Pt 1):181-90.

[110] Dodds RA, Connor JR, James IE, Rykaczewski EL, Appelbaum E, Dul E, et al. Human osteoclasts, not osteoblasts, deposit osteopontin onto resorption surfaces: an in vitro and ex vivo study of remodeling bone. J Bone Miner Res. 1995;10(11):1666-80. 
[111] Pullig O, Weseloh G, Gauer S, Swoboda B. Osteopontin is expressed by adult human osteoarthritic chondrocytes: protein and mRNA analysis of normal and osteoarthritic cartilage. Matrix Biol. 2000;19(3):245-55.

[112] Honsawek S, Tanavalee A, Sakdinakiattikoon M, Chayanupatkul M, Yuktanandana P. Correlation of plasma and synovial fluid osteopontin with disease severity in knee osteoarthritis. Clin Biochem. 2009;42(9):808-12.

[113] Gao SG, Li KH, Zeng KB, Tu M, Xu M, Lei GH. Elevated osteopontin level of synovial fluid and articular cartilage is associated with disease severity in knee osteoarthritis patients. Osteoarthritis Cartilage.18(1):82-7.

[114] Rosenthal AK, Gohr CM, Uzuki M, Masuda I. Osteopontin promotes pathologic mineralization in articular cartilage. Matrix Biol. 2007;26(2):96-105.

[115] Gericke A, Qin C, Spevak L, Fujimoto Y, Butler WT, Sorensen ES, et al. Importance of phosphorylation for osteopontin regulation of biomineralization. Calcif Tissue Int. 2005;77(1):45-54.

[116] Attur MG, Dave MN, Stuchin S, Kowalski AJ, Steiner G, Abramson SB, et al. Osteopontin: an intrinsic inhibitor of inflammation in cartilage. Arthritis Rheum. 2001;44(3):578-84.

[117] Matsui Y, Iwasaki N, Kon S, Takahashi D, Morimoto J, Denhardt DT, et al. Accelerated development of aging-associated and instability-induced osteoarthritis in osteopontin-deficient mice. Arthritis Rheum. 2009;60(8):2362-71.

[118] Jundt G, Berghauser KH, Termine JD, Schulz A. Osteonectin--a differentiation marker of bone cells. Cell Tissue Res. 1987;248(2):409-15.

[119] Chandrasekhar S, Harvey AK, Johnson MG, Becker GW. Osteonectin/SPARC is a product of articular chondrocytes/cartilage and is regulated by cytokines and growth factors. Biochim Biophys Acta. 1994;1221(1):7-14.

[120] Nakamura S, Kamihagi K, Satakeda H, Katayama M, Pan H, Okamoto H, et al. Enhancement of SPARC (osteonectin) synthesis in arthritic cartilage. Increased levels in synovial fluids from patients with rheumatoid arthritis and regulation by growth factors and cytokines in chondrocyte cultures. Arthritis Rheum. 1996;39(4):539-51.

[121] Nanba Y, Nishida K, Yoshikawa T, Sato T, Inoue H, Kuboki Y. Expression of osteonectin in articular cartilage of osteoarthritic knees. Acta Med Okayama. 1997;51(5):239-43.

[122] Tremble PM, Lane TF, Sage EH, Werb Z. SPARC, a secreted protein associated with morphogenesis and tissue remodeling, induces expression of metalloproteinases in fibroblasts through a novel extracellular matrix-dependent pathway. J Cell Biol. 1993;121(6):1433-44.

[123] Arend WP, Welgus HG, Thompson RC, Eisenberg SP. Biological properties of recombinant human monocyte-derived interleukin 1 receptor antagonist. J Clin Invest. 1990;85(5):1694-7.

[124] Smith RJ, Chin JE, Sam LM, Justen JM. Biologic effects of an interleukin-1 receptor antagonist protein on interleukin-1-stimulated cartilage erosion and chondrocyte responsiveness. Arthritis Rheum. 1991;34(1):78-83. 
[125] Woodell-May J, Matuska A, Oyster M, Welch Z, O'Shaughnessey K, Hoeppner J. Autologous protein solution inhibits MMP-13 production by IL-1beta and TNFalpha-stimulated human articular chondrocytes. J Orthop Res.

[126] Pelletier JP, Mineau F, Ranger P, Tardif G, Martel-Pelletier J. The increased synthesis of inducible nitric oxide inhibits IL-1ra synthesis by human articular chondrocytes: possible role in osteoarthritic cartilage degradation. Osteoarthritis Cartilage. 1996;4(1):77-84.

[127] Baragi VM, Renkiewicz RR, Jordan H, Bonadio J, Hartman JW, Roessler BJ. Transplantation of transduced chondrocytes protects articular cartilage from interleukin 1-induced extracellular matrix degradation. $\mathrm{J}$ Clin Invest. 1995;96(5):2454-60.

[128] Muller-Ladner U, Roberts CR, Franklin BN, Gay RE, Robbins PD, Evans CH, et al. Human IL-1Ra gene transfer into human synovial fibroblasts is chondroprotective. J Immunol. 1997;158(7):3492-8.

[129] Caron JP, Fernandes JC, Martel-Pelletier J, Tardif G, Mineau F, Geng C, et al. Chondroprotective effect of intraarticular injections of interleukin-1 receptor antagonist in experimental osteoarthritis. Suppression of collagenase-1 expression. Arthritis Rheum. 1996;39(9):1535-44.

[130] Doi H, Nishida K, Yorimitsu M, Komiyama T, Kadota Y, Tetsunaga T, et al. Interleukin-4 downregulates the cyclic tensile stress-induced matrix metalloproteinases-13 and cathepsin B expression by rat normal chondrocytes. Acta Med Okayama. 2008;62(2):119-26.

[131] Yorimitsu M, Nishida K, Shimizu A, Doi H, Miyazawa S, Komiyama T, et al. Intraarticular injection of interleukin-4 decreases nitric oxide production by chondrocytes and ameliorates subsequent destruction of cartilage in instabilityinduced osteoarthritis in rat knee joints. Osteoarthritis Cartilage. 2008;16(7):764-71.

[132] Yeh LA, Augustine AJ, Lee P, Riviere LR, Sheldon A. Interleukin-4, an inhibitor of cartilage breakdown in bovine articular cartilage explants. J Rheumatol. 1995;22(9):1740-6.

[133] Relic B, Guicheux J, Mezin F, Lubberts E, Togninalli D, Garcia I, et al. Il-4 and IL-13, but not IL-10, protect human synoviocytes from apoptosis. J Immunol. 2001;166(4):2775-82.

[134] Manning K, Rachakonda PS, Rai MF, Schmidt MF. Co-expression of insulin-like growth factor-1 and interleukin-4 in an in vitro inflammatory model. Cytokine.50(3):297-305.

[135] Iannone F, De Bari C, Dell'Accio F, Covelli M, Cantatore FP, Patella V, et al. Interleukin-10 and interleukin-10 receptor in human osteoarthritic and healthy chondrocytes. Clin Exp Rheumatol. 2001;19(2):139-45.

[136] Fernandes JC, Martel-Pelletier J, Pelletier JP. The role of cytokines in osteoarthritis pathophysiology. Biorheology. 2002;39(1-2):237-46.

[137] Zhang X, Mao Z, Yu C. Suppression of early experimental osteoarthritis by gene transfer of interleukin-1 receptor antagonist and interleukin-10. J Orthop Res. 2004;22(4):742-50. 
[138] Maier R, Ganu V, Lotz M. Interleukin-11, an inducible cytokine in human articular chondrocytes and synoviocytes, stimulates the production of the tissue inhibitor of metalloproteinases. J Biol Chem. 1993;268(29):21527-32.

[139] Trepicchio WL, Dorner AJ. The therapeutic utility of Interleukin-11 in the treatment of inflammatory disease. Expert Opin Investig Drugs. 1998;7(9):1501-4.

[140] Alaaeddine N, Di Battista JA, Pelletier JP, Kiansa K, Cloutier JM, Martel-Pelletier J. Differential effects of IL-8, LIF (pro-inflammatory) and IL-11 (anti-inflammatory) on TNF-alpha-induced PGE(2)release and on signalling pathways in human OA synovial fibroblasts. Cytokine. 1999;11(12):1020-30.

[141] Hermann JA, Hall MA, Maini RN, Feldmann M, Brennan FM. Important immunoregulatory role of interleukin-11 in the inflammatory process in rheumatoid arthritis. Arthritis Rheum. 1998;41(8):1388-97.

[142] Walmsley M, Butler DM, Marinova-Mutafchieva L, Feldmann M. An antiinflammatory role for interleukin-11 in established murine collagen-induced arthritis. Immunology. 1998;95(1):31-7.

[143] Trontzas P, Kamper EF, Potamianou A, Kyriazis NC, Kritikos H, Stavridis J. Comparative study of serum and synovial fluid interleukin-11 levels in patients with various arthritides. Clin Biochem. 1998;31(8):673-9.

[144] Tardif G, Pelletier JP, Dupuis M, Geng C, Cloutier JM, Martel-Pelletier J. Collagenase 3 production by human osteoarthritic chondrocytes in response to growth factors and cytokines is a function of the physiologic state of the cells. Arthritis Rheum. 1999;42(6):1147-58.

[145] Chabaud M, Durand JM, Buchs N, Fossiez F, Page G, Frappart L, et al. Human interleukin-17: A $\mathrm{T}$ cell-derived proinflammatory cytokine produced by the rheumatoid synovium. Arthritis Rheum. 1999;42(5):963-70.

[146] Jovanovic D, Pelletier JP, Alaaeddine N, Mineau F, Geng C, Ranger P, et al. Effect of IL-13 on cytokines, cytokine receptors and inhibitors on human osteoarthritis synovium and synovial fibroblasts. Osteoarthritis Cartilage. 1998;6(1):40-9.

[147] Alaaeddine N, Di Battista JA, Pelletier JP, Kiansa K, Cloutier JM, Martel-Pelletier J. Inhibition of tumor necrosis factor alpha-induced prostaglandin E2 production by the antiinflammatory cytokines interleukin-4, interleukin-10, and interleukin-13 in osteoarthritic synovial fibroblasts: distinct targeting in the signaling pathways. Arthritis Rheum. 1999;42(4):710-8.

[148] Woods JM, Haines GK, Shah MR, Rayan G, Koch AE. Low-level production of interleukin-13 in synovial fluid and tissue from patients with arthritis. Clin Immunol Immunopathol. 1997;85(2):210-20.

[149] Fortier LA, Barker JU, Strauss EJ, McCarrel TM, Cole BJ. The Role of Growth Factors in Cartilage Repair. Clin Orthop Relat Res.

[150] Chubinskaya S, Segalite D, Pikovsky D, Hakimiyan AA, Rueger DC. Effects induced by BMPS in cultures of human articular chondrocytes: comparative studies. Growth Factors. 2008;26(5):275-83.

[151] Chubinskaya S, Hurtig M, Rueger DC. OP-1/BMP-7 in cartilage repair. Int Orthop. 2007;31(6):773-81. 
[152] van der Kraan PM, Blaney Davidson EN, van den Berg WB. A role for age-related changes in TGFbeta signaling in aberrant chondrocyte differentiation and osteoarthritis. Arthritis Res Ther.12(1):201.

[153] Blaney Davidson EN, van der Kraan PM, van den Berg WB. TGF-beta and osteoarthritis. Osteoarthritis Cartilage. 2007;15(6):597-604.

[154] Fan J, Gong Y, Ren L, Varshney RR, Cai D, Wang DA. In vitro engineered cartilage using synovium-derived mesenchymal stem cells with injectable gellan hydrogels. Acta Biomater.6(3):1178-85.

[155] Kizawa H, Kou I, Iida A, Sudo A, Miyamoto Y, Fukuda A, et al. An aspartic acid repeat polymorphism in asporin inhibits chondrogenesis and increases susceptibility to osteoarthritis. Nat Genet. 2005;37(2):138-44.

[156] Jiang Q, Shi D, Yi L, Ikegawa S, Wang Y, Nakamura T, et al. Replication of the association of the aspartic acid repeat polymorphism in the asporin gene with kneeosteoarthritis susceptibility in Han Chinese. J Hum Genet. 2006;51(12):1068-72.

[157] Yang X, Chen L, Xu X, Li C, Huang C, Deng CX. TGF-beta/Smad3 signals repress chondrocyte hypertrophic differentiation and are required for maintaining articular cartilage. J Cell Biol. 2001;153(1):35-46.

[158] Serra R, Johnson M, Filvaroff EH, LaBorde J, Sheehan DM, Derynck R, et al. Expression of a truncated, kinase-defective TGF-beta type II receptor in mouse skeletal tissue promotes terminal chondrocyte differentiation and osteoarthritis. J Cell Biol. 1997;139(2):541-52.

[159] Blaney Davidson EN, Scharstuhl A, Vitters EL, van der Kraan PM, van den Berg WB. Reduced transforming growth factor-beta signaling in cartilage of old mice: role in impaired repair capacity. Arthritis Res Ther. 2005;7(6):R1338-47.

[160] Morales TI. Transforming growth factor-beta 1 stimulates synthesis of proteoglycan aggregates in calf articular cartilage organ cultures. Arch Biochem Biophys. 1991;286(1):99-106.

[161] Bakker AC, van de Loo FA, van Beuningen HM, Sime P, van Lent PL, van der Kraan $\mathrm{PM}$, et al. Overexpression of active TGF-beta-1 in the murine knee joint: evidence for synovial-layer-dependent chondro-osteophyte formation. Osteoarthritis Cartilage. 2001;9(2):128-36.

[162] Livne E, Laufer D, Blumenfeld I. Differential response of articular cartilage from young growing and mature old mice to IL-1 and TGF-beta. Arch Gerontol Geriatr. 1997;24(2):211-21.

[163] Gouttenoire J, Valcourt U, Ronziere MC, Aubert-Foucher E, Mallein-Gerin F, Herbage D. Modulation of collagen synthesis in normal and osteoarthritic cartilage. Biorheology. 2004;41(3-4):535-42.

[164] Arai Y, Kubo T, Kobayashi K, Takeshita K, Takahashi K, Ikeda T, et al. Adenovirus vector-mediated gene transduction to chondrocytes: in vitro evaluation of therapeutic efficacy of transforming growth factor-beta 1 and heat shock protein 70 gene transduction. J Rheumatol. 1997;24(9):1787-95.

[165] Blaney Davidson EN, Vitters EL, van Lent PL, van de Loo FA, van den Berg WB, van der Kraan PM. Elevated extracellular matrix production and degradation upon 
bone morphogenetic protein-2 (BMP-2) stimulation point toward a role for BMP-2 in cartilage repair and remodeling. Arthritis Res Ther. 2007;9(5):R102.

[166] Im HJ, Pacione C, Chubinskaya S, Van Wijnen AJ, Sun Y, Loeser RF. Inhibitory effects of insulin-like growth factor-1 and osteogenic protein-1 on fibronectin fragmentand interleukin-1beta-stimulated matrix metalloproteinase-13 expression in human chondrocytes. J Biol Chem. 2003;278(28):25386-94.

[167] Flechtenmacher J, Huch K, Thonar EJ, Mollenhauer JA, Davies SR, Schmid TM, et al. Recombinant human osteogenic protein 1 is a potent stimulator of the synthesis of cartilage proteoglycans and collagens by human articular chondrocytes. Arthritis Rheum. 1996;39(11):1896-904.

[168] Imai Y, Okuma M, An HS, Nakagawa K, Yamada M, Muehleman C, et al. Restoration of disc height loss by recombinant human osteogenic protein-1 injection into intervertebral discs undergoing degeneration induced by an intradiscal injection of chondroitinase ABC. Spine (Phila Pa 1976). 2007;32(11):1197-205.

[169] Loeser RF, Pacione CA, Chubinskaya S. The combination of insulin-like growth factor 1 and osteogenic protein 1 promotes increased survival of and matrix synthesis by normal and osteoarthritic human articular chondrocytes. Arthritis Rheum. 2003;48(8):2188-96.

[170] Merrihew C, Kumar B, Heretis K, Rueger DC, Kuettner KE, Chubinskaya S. Alterations in endogenous osteogenic protein-1 with degeneration of human articular cartilage. J Orthop Res. 2003;21(5):899-907.

[171] Chubinskaya S, Kumar B, Merrihew C, Heretis K, Rueger DC, Kuettner KE. Agerelated changes in cartilage endogenous osteogenic protein-1 (OP-1). Biochim Biophys Acta. 2002;1588(2):126-34.

[172] Miyamoto C, Matsumoto T, Sakimura K, Shindo H. Osteogenic protein-1 with transforming growth factor-beta1: potent inducer of chondrogenesis of synovial mesenchymal stem cells in vitro. J Orthop Sci. 2007;12(6):555-61.

[173] Jelic M, Pecina M, Haspl M, Kos J, Taylor K, Maticic D, et al. Regeneration of articular cartilage chondral defects by osteogenic protein-1 (bone morphogenetic protein-7) in sheep. Growth Factors. 2001;19(2):101-13.

[174] Luyten FP, Hascall VC, Nissley SP, Morales TI, Reddi AH. Insulin-like growth factors maintain steady-state metabolism of proteoglycans in bovine articular cartilage explants. Arch Biochem Biophys. 1988;267(2):416-25.

[175] Sah RL, Chen AC, Grodzinsky AJ, Trippel SB. Differential effects of bFGF and IGF-I on matrix metabolism in calf and adult bovine cartilage explants. Arch Biochem Biophys. 1994;308(1):137-47.

[176] Ekenstedt KJ, Sonntag WE, Loeser RF, Lindgren BR, Carlson CS. Effects of chronic growth hormone and insulin-like growth factor 1 deficiency on osteoarthritis severity in rat knee joints. Arthritis Rheum. 2006;54(12):3850-8.

[177] Goodrich LR, Hidaka C, Robbins PD, Evans CH, Nixon AJ. Genetic modification of chondrocytes with insulin-like growth factor-1 enhances cartilage healing in an equine model. J Bone Joint Surg Br. 2007;89(5):672-85.

[178] Fortier LA, Mohammed HO, Lust G, Nixon AJ. Insulin-like growth factor-I enhances cell-based repair of articular cartilage. J Bone Joint Surg Br. 2002;84(2):276-88. 
[179] Osada R, Ohshima H, Ishihara H, Yudoh K, Sakai K, Matsui H, et al. Autocrine/paracrine mechanism of insulin-like growth factor-1 secretion, and the effect of insulin-like growth factor-1 on proteoglycan synthesis in bovine intervertebral discs. J Orthop Res. 1996;14(5):690-9.

[180] Gruber HE, Norton HJ, Hanley EN, Jr. Anti-apoptotic effects of IGF-1 and PDGF on human intervertebral disc cells in vitro. Spine (Phila Pa 1976). 2000;25(17):2153-7.

[181] Loeser RF, Shanker G, Carlson CS, Gardin JF, Shelton BJ, Sonntag WE. Reduction in the chondrocyte response to insulin-like growth factor 1 in aging and osteoarthritis: studies in a non-human primate model of naturally occurring disease. Arthritis Rheum. 2000;43(9):2110-20.

[182] Boehm AK, Seth M, Mayr KG, Fortier LA. Hsp90 mediates insulin-like growth factor 1 and interleukin-1beta signaling in an age-dependent manner in equine articular chondrocytes. Arthritis Rheum. 2007;56(7):2335-43.

[183] Morales TI. The quantitative and functional relation between insulin-like growth factor-I (IGF) and IGF-binding proteins during human osteoarthritis. J Orthop Res. 2008;26(4):465-74.

[184] Wang Z, Huang Y, Zou J, Cao K, Xu Y, Wu JM. Effects of red wine and wine polyphenol resveratrol on platelet aggregation in vivo and in vitro. Int J Mol Med. 2002;9(1):77-9.

[185] Orallo F, Alvarez E, Camina M, Leiro JM, Gomez E, Fernandez P. The possible implication of trans-Resveratrol in the cardioprotective effects of long-term moderate wine consumption. Mol Pharmacol. 2002;61(2):294-302.

[186] Haider UG, Sorescu D, Griendling KK, Vollmar AM, Dirsch VM. Resveratrol suppresses angiotensin II-induced Akt/protein kinase B and p70 S6 kinase phosphorylation and subsequent hypertrophy in rat aortic smooth muscle cells. Mol Pharmacol. 2002;62(4):772-7.

[187] Bhat KPL, Kosmeder JW, 2nd, Pezzuto JM. Biological effects of resveratrol. Antioxid Redox Signal. 2001;3(6):1041-64.

[188] Bertelli AA, Ferrara F, Diana G, Fulgenzi A, Corsi M, Ponti W, et al. Resveratrol, a natural stilbene in grapes and wine, enhances intraphagocytosis in human promonocytes: a co-factor in antiinflammatory and anticancer chemopreventive activity. Int J Tissue React. 1999;21(4):93-104.

[189] Fremont L. Biological effects of resveratrol. Life Sci. 2000;66(8):663-73.

[190] Huang KS, Lin M, Cheng GF. Anti-inflammatory tetramers of resveratrol from the roots of Vitis amurensis and the conformations of the seven-membered ring in some oligostilbenes. Phytochemistry. 2001;58(2):357-62.

[191] Jang M, Cai L, Udeani GO, Slowing KV, Thomas CF, Beecher CW, et al. Cancer chemopreventive activity of resveratrol, a natural product derived from grapes. Science. 1997;275(5297):218-20.

[192] Martinez J, Moreno JJ. Effect of resveratrol, a natural polyphenolic compound, on reactive oxygen species and prostaglandin production. Biochem Pharmacol. 2000;59(7):865-70.

[193] Ignatowicz E, Baer-Dubowska W. Resveratrol, a natural chemopreventive agent against degenerative diseases. Pol J Pharmacol. 2001;53(6):557-69. 
[194] Leiro J, Alvarez E, Arranz JA, Laguna R, Uriarte E, Orallo F. Effects of cis-resveratrol on inflammatory murine macrophages: antioxidant activity and down-regulation of inflammatory genes. J Leukoc Biol. 2004;75(6):1156-65.

[195] Elmali N, Esenkaya I, Harma A, Ertem K, Turkoz Y, Mizrak B. Effect of resveratrol in experimental osteoarthritis in rabbits. Inflamm Res. 2005;54(4):158-62.

[196] Elmali N, Baysal O, Harma A, Esenkaya I, Mizrak B. Effects of resveratrol in inflammatory arthritis. Inflammation. 2007;30(1-2):1-6.

[197] Shakibaei M, John T, Seifarth C, Mobasheri A. Resveratrol inhibits IL-1 beta-induced stimulation of caspase-3 and cleavage of PARP in human articular chondrocytes in vitro. Ann N Y Acad Sci. 2007;1095:554-63.

[198] Csaki C, Keshishzadeh N, Fischer K, Shakibaei M. Regulation of inflammation signalling by resveratrol in human chondrocytes in vitro. Biochem Pharmacol. 2008;75(3):677-87.

[199] Li X, Phillips FM, An HS, Ellman M, Thonar EJ, Wu W, et al. The action of resveratrol, a phytoestrogen found in grapes, on the intervertebral disc. Spine (Phila Pa 1976). 2008;33(24):2586-95.

[200] Gitay-Goren H, Soker S, Vlodavsky I, Neufeld G. The binding of vascular endothelial growth factor to its receptors is dependent on cell surface-associated heparin-like molecules. J Biol Chem. 1992;267(9):6093-8.

[201] Baker EN, Baker HM. A structural framework for understanding the multifunctional character of lactoferrin. Biochimie. 2009;91(1):3-10.

[202] Mader JS, Richardson A, Salsman J, Top D, de Antueno R, Duncan R, et al. Bovine lactoferricin causes apoptosis in Jurkat T-leukemia cells by sequential permeabilization of the cell membrane and targeting of mitochondria. Exp Cell Res. 2007;313(12):2634-50.

[203] Gifford JL, Hunter HN, Vogel HJ. Lactoferricin: a lactoferrin-derived peptide with antimicrobial, antiviral, antitumor and immunological properties. Cell Mol Life Sci. 2005;62(22):2588-98.

[204] Henrotin YE, Bruckner P, Pujol JP. The role of reactive oxygen species in homeostasis and degradation of cartilage. Osteoarthritis Cartilage. 2003;11(10):747-55.

[205] Guillen C, McInnes IB, Vaughan D, Speekenbrink AB, Brock JH. The effects of local administration of lactoferrin on inflammation in murine autoimmune and infectious arthritis. Arthritis Rheum. 2000;43(9):2073-80.

[206] Hayashida K, Kaneko T, Takeuchi T, Shimizu H, Ando K, Harada E. Oral administration of lactoferrin inhibits inflammation and nociception in rat adjuvantinduced arthritis. J Vet Med Sci. 2004;66(2):149-54.

[207] Wong SH, Francis N, Chahal H, Raza K, Salmon M, Scheel-Toellner D, et al. Lactoferrin is a survival factor for neutrophils in rheumatoid synovial fluid. Rheumatology (Oxford). 2009;48(1):39-44.

[208] Cornish J, Callon KE, Naot D, Palmano KP, Banovic T, Bava U, et al. Lactoferrin is a potent regulator of bone cell activity and increases bone formation in vivo. Endocrinology. 2004;145(9):4366-74. 
[209] Kim JS, Ellman MB, An HS, Yan D, van Wijnen AJ, Murphy G, et al. Lactoferricin mediates anabolic and anti-catabolic effects in the intervertebral disc. J Cell Physiol.

[210] Sprangers MA, de Regt EB, Andries F, van Agt HM, Bijl RV, de Boer JB, et al. Which chronic conditions are associated with better or poorer quality of life? J Clin Epidemiol. 2000;53(9):895-907.

[211] Dray A, Read SJ. Arthritis and pain. Future targets to control osteoarthritis pain. Arthritis Res Ther. 2007;9(3):212.

[212] Creamer P, Hunt M, Dieppe P. Pain mechanisms in osteoarthritis of the knee: effect of intraarticular anesthetic. J Rheumatol. 1996;23(6):1031-6.

[213] Kosek E, Ordeberg G. Lack of pressure pain modulation by heterotopic noxious conditioning stimulation in patients with painful osteoarthritis before, but not following, surgical pain relief. Pain. 2000;88(1):69-78.

[214] Loeser RF, Yammani RR, Carlson CS, Chen H, Cole A, Im HJ, et al. Articular chondrocytes express the receptor for advanced glycation end products: Potential role in osteoarthritis. Arthritis Rheum. 2005;52(8):2376-85.

[215] Li X, An HS, Ellman M, Phillips F, Thonar EJ, Park DK, et al. Action of fibroblast growth factor-2 on the intervertebral disc. Arthritis Res Ther. 2008;10(2):R48.

[216] Schaible HG, Richter F, Ebersberger A, Boettger MK, Vanegas H, Natura G, et al. Joint pain. Exp Brain Res. 2009;196(1):153-62.

[217] Sommer C, Kress M. Recent findings on how proinflammatory cytokines cause pain: peripheral mechanisms in inflammatory and neuropathic hyperalgesia. Neurosci Lett. 2004;361(1-3):184-7.

[218] Brenn D, Richter F, Schaible HG. Sensitization of unmyelinated sensory fibers of the joint nerve to mechanical stimuli by interleukin-6 in the rat: an inflammatory mechanism of joint pain. Arthritis Rheum. 2007;56(1):351-9.

[219] Arvidson NG, Gudbjornsson B, Elfman L, Ryden AC, Totterman TH, Hallgren R. Circadian rhythm of serum interleukin-6 in rheumatoid arthritis. Ann Rheum Dis. 1994;53(8):521-4.

[220] Desgeorges A, Gabay C, Silacci P, Novick D, Roux-Lombard P, Grau G, et al. Concentrations and origins of soluble interleukin 6 receptor-alpha in serum and synovial fluid. J Rheumatol. 1997;24(8):1510-6.

[221] Obreja O, Biasio W, Andratsch M, Lips KS, Rathee PK, Ludwig A, et al. Fast modulation of heat-activated ionic current by proinflammatory interleukin 6 in rat sensory neurons. Brain. 2005;128(Pt 7):1634-41.

[222] Ohtori S, Takahashi K, Moriya H, Myers RR. TNF-alpha and TNF-alpha receptor type 1 upregulation in glia and neurons after peripheral nerve injury: studies in murine DRG and spinal cord. Spine (Phila Pa 1976). 2004;29(10):1082-8.

[223] Schafers M, Marziniak M, Sorkin LS, Yaksh TL, Sommer C. Cyclooxygenase inhibition in nerve-injury- and TNF-induced hyperalgesia in the rat. Exp Neurol. 2004;185(1):160-8.

[224] Grunke M, Schulze-Koops H. Successful treatment of inflammatory knee osteoarthritis with tumour necrosis factor blockade. Ann Rheum Dis. 2006;65(4):555-6. 
[225] Inglis JJ, Notley CA, Essex D, Wilson AW, Feldmann M, Anand P, et al. Collageninduced arthritis as a model of hyperalgesia: functional and cellular analysis of the analgesic actions of tumor necrosis factor blockade. Arthritis Rheum. 2007;56(12):4015-23.

[226] Yaksh TL, Dirig DM, Conway CM, Svensson C, Luo ZD, Isakson PC. The acute antihyperalgesic action of nonsteroidal, anti-inflammatory drugs and release of spinal prostaglandin E2 is mediated by the inhibition of constitutive spinal cyclooxygenase-2 (COX-2) but not COX-1. J Neurosci. 2001;21(16):5847-53.

[227] England S, Bevan S, Docherty RJ. PGE2 modulates the tetrodotoxin-resistant sodium current in neonatal rat dorsal root ganglion neurones via the cyclic AMP-protein kinase A cascade. J Physiol. 1996;495 ( Pt 2):429-40.

[228] Bar KJ, Natura G, Telleria-Diaz A, Teschner P, Vogel R, Vasquez E, et al. Changes in the effect of spinal prostaglandin E2 during inflammation: prostaglandin E (EP1$\mathrm{EP} 4)$ receptors in spinal nociceptive processing of input from the normal or inflamed knee joint. J Neurosci. 2004;24(3):642-51.

[229] Castro RR, Cunha FQ, Silva FS, Jr., Rocha FA. A quantitative approach to measure joint pain in experimental osteoarthritis--evidence of a role for nitric oxide. Osteoarthritis Cartilage. 2006;14(8):769-76.

[230] Claveau D, Sirinyan M, Guay J, Gordon R, Chan CC, Bureau Y, et al. Microsomal prostaglandin E synthase- 1 is a major terminal synthase that is selectively upregulated during cyclooxygenase-2-dependent prostaglandin E2 production in the rat adjuvant-induced arthritis model. J Immunol. 2003;170(9):4738-44.

[231] Trebino CE, Stock JL, Gibbons CP, Naiman BM, Wachtmann TS, Umland JP, et al. Impaired inflammatory and pain responses in mice lacking an inducible prostaglandin E synthase. Proc Natl Acad Sci U S A. 2003;100(15):9044-9. 


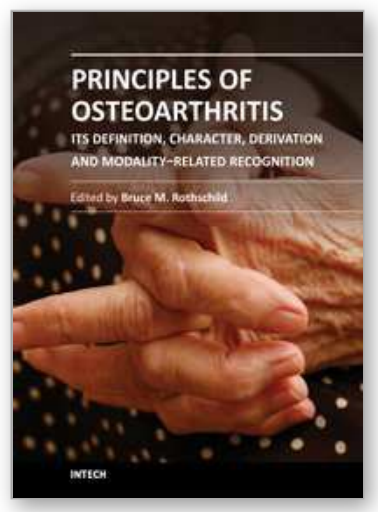

\section{Principles of Osteoarthritis- Its Definition, Character, Derivation and Modality-Related Recognition}

Edited by Dr. Bruce M. Rothschild

ISBN 978-953-51-0063-8

Hard cover, 590 pages

Publisher InTech

Published online 22, February, 2012

Published in print edition February, 2012

This volume addresses the nature of the most common form of arthritis in humans. If osteoarthritis is inevitable (only premature death prevents all of us from being afflicted), it seems essential to facilitate its recognition, prevention, options, and indications for treatment. Progress in understanding this disease has occurred with recognition that it is not simply a degenerative joint disease. Causative factors, such as joint malalignment, ligamentous abnormalities, overuse, and biomechanical and metabolic factors have been recognized as amenable to intervention; genetic factors, less so; with metabolic diseases, intermediate. Its diagnosis is based on recognition of overgrowth of bone at joint margins. This contrasts with overgrowth of bone at vertebral margins, which is not a symptomatic phenomenon and has been renamed spondylosis deformans.

Osteoarthritis describes an abnormality of joints, but the severity does not necessarily produce pain. The patient and his/her symptoms need to be treated, not the x-ray.

\section{How to reference}

In order to correctly reference this scholarly work, feel free to copy and paste the following:

Michael B. Ellman, Dongyao Yan, Di Chen and Hee-Jeong Im (2012). Biochemical Mediators Involved in Cartilage Degradation and the Induction of Pain in Osteoarthritis, Principles of Osteoarthritis- Its Definition, Character, Derivation and Modality-Related Recognition, Dr. Bruce M. Rothschild (Ed.), ISBN: 978-953-510063-8, InTech, Available from: http://www.intechopen.com/books/principles-of-osteoarthritis-its-definitioncharacter-derivation-and-modality-related-recognition/biochemical-mediators-involved-in-cartilagedegradation-and-the-induction-of-pain-in-osteoarthritis

\section{INTECH}

open science | open minds

\section{InTech Europe}

University Campus STeP Ri

Slavka Krautzeka 83/A

51000 Rijeka, Croatia

Phone: +385 (51) 770447

Fax: +385 (51) 686166

www.intechopen.com

\section{InTech China}

Unit 405, Office Block, Hotel Equatorial Shanghai

No.65, Yan An Road (West), Shanghai, 200040, China 中国上海市延安西路65号上海国际贵都大饭店办公楼405单元

Phone: +86-21-62489820

Fax: +86-21-62489821 
(C) 2012 The Author(s). Licensee IntechOpen. This is an open access article distributed under the terms of the Creative Commons Attribution 3.0 License, which permits unrestricted use, distribution, and reproduction in any medium, provided the original work is properly cited. 